\title{
Gustaf Nyström ja Suomen puukirkkojen ainutlaatuisuus
}

\section{Anna Ripatti}

Tämän artikkelin tavoitteena on esittää uusi tulkinta Suomen 1600- ja 1700-luvuilla rakennettujen puukirkkojen ja etenkin niin sanottujen pohjalaisten tukipilarikirkkojen varhaisesta tutkimushistoriasta. ${ }^{1}$ Puukirkkotutkimusten alkuvaiheet ajoitetaan yleensä 1920-luvulle, mutta ne alkoivat jo huomattavasti aiemmin. Puukirkkojen arvostus muuttui ratkaisevasti 1890-luvun kuluessa, ja 1900-luvun vaihteessa niistä tuli yleisesti arvostettua rakennusperintöä. Arkkitehti Gustaf Nyström (1856-1917) ymmärsi ensimmäisenä tutkijana pohjalaisen tukipilarirakenteen ainutlaatuisuuden. Nyström luennoi löydöistään, mutta hänen suunnittelemansa julkaisu Suomen puukirkkoarkkitehtuurista ei koskaan valmistunut. Siksi hänen tutkimuk- sensa ovat jääneet tähän asti lähes kokonaan vaille huomiota.

Saloisten kirkon tutkimushistoriaa selvittäessään Lars Pettersson mainitsi Gustaf Nyströmin varhaisena puukirkkojen tutkijana. ${ }^{2}$ Hän totesi Nyströmin yksittäiseen julkaisuun viitaten, että "Nyström on nähtävästi ensimmäisenä oivaltanut pohjalaisen tukipilarikirkon erikoisuuden."3 Petterssonin tarjoama tutkimuksellinen johtolanka sittemmin unohtui, eikä Nyströmin julkaisemattomia puukirkkotutkimuksia ole aiemmin tutkittu lainkaan. Tutkijat ovat sitä vastoin esittäneet pohjalaisen tukipilarirakenteen varhaisesta tutkimushistoriasta erilaisia tulkintoja. Henrik Liliuksen mukaan 1930-luvun lopussa puukirkkotutkimuksensa aloittanut Lars Pettersson löysi pohjalaisten tukipilareiden mielenkiintoisen rakenteen. ${ }^{4}$ Petterssonin yksityiskohtaiset tutkimukset mitä ilmeisimmin johtivat tähän mielikuvaan. Renja
Suominen-Kokkonen on vastikään kyseenalaistanut tämän tulkinnan. Hän on esittänyt, että wieniläisen taidehistorioitsija Josef Strzygowskin kirjoitukset pohjalaisista tukipilarikirkoista vaikuttivat Petterssonin näkemyksiin kyseistä rakennetta koskien. ${ }^{5}$ Strzygowski esitetäänkin toistuvasti Suomen puukirkkoarkkitehtuurin arvojen löytäjänä. Hänen 1920-luvun alun tutkimuksensa on nähty alkuna paitsi puukirkkojen tutkimiselle myös kiinnostukselle niitä kohtaan. ${ }^{6}$ Strzygowski tulkitsi Suomen puukirkot itsenäiseksi rakennusryhmäksi, jotka todistivat pohjoisen kansan ikiaikaisesta ilmaisuvoimasta. Vuonna 1923 hän kirjoitti, että Länsi- ja Pohjois-Suomen kirkkojen hirsistä salvotut tukipilarit olivat "yksi nerokkaimmista ratkaisuista, mitä puurakennustaiteessa on milloinkaan tehty". ${ }^{7}$ Pohjalaisten tukipilarikirkkojen rakenteelliset ratkaisut ja kiinnostus puukirkkojen arkkitehtuuriin eivät kuiten-

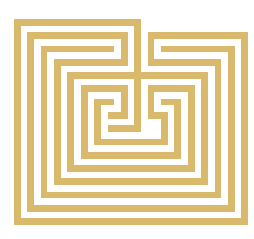


kaan olleet tuolloin uutuus. Gustaf Nyström luennoi opiskelijoilleen ja laajalle yleisölle Suomen puukirkkoarkkitehtuurin erityispiirteistä 1900-luvun alkuvuosista lähtien. Tukipilarirakenteiden erityisyys oli arkkitehtuurin asiantuntijoiden ja todennäköisesti myös muiden asiaa harrastaneiden tiedossa viimeistään 1910-luvulla.

Suomen rakennussuojelun ja restauroinnin historioissa Gustaf Nyström esiintyy usein taustavaikuttajana. Hän oli Muinaistieteellisen toimikunnan jäsen vuosina 18971908 ja ajoi voimakkaasti näkemystä, jonka mukaan vanhojen rakennusten restauroinnin tuli perustua mahdollisimman tarkoille rakennuksessa paikan päällä tehtäville tutkimuksille. ${ }^{8}$ Mahdollistaakseen tämän tärkeänä pitämänsä periaatteen Nyström pyrki kouluttamaan tulevista arkkitehdeista rakennusperinnön tutkimisen ammattilaisia. Hän aloitti arkkitehtiopiskelijoiden yhteiset mittauspiirustusmatkat, joiden aikana opiskelijat harjaantuivat rakennusten mittaamiseen ja dokumentointiin. Nämä dokumentointimatkat muodostivat Nyströmin tutkimustoiminnan ytimen. Ne suuntautuivat aluksi keskiaikaisiin kivikirkkoihin, mutta ne olivat tärkeitä myös puukirkkojen arvonnousulle. Arkki- tehtiopiskelijoiden mittauspiirustusmatkojen historiaa ei kuitenkaan ole varsinaisesti tutkittu, vaikka tutkijat sivuavat niitä usein ja vaikka Vilhelm Helander on kirjoittanut niistä yleisesityksen. $^{9}$ Tämä johtuu todennäköisesti lähteiden hajanaisuudesta ja siitä, että niistä tunnetaan toistaiseksi vain niukasti kirjallisia lähteitä. Teknillisen korkeakoulun mittauspiirustusmatkojen merkitys kotimaan rakennusperinnön tutkimisessa ja tunnetuksi tekemisessä oli 1800-luvun lopussa ja 1900-luvun alussa huomattava ja limittyi Suomen Muinaismuistoyhdistyksen taidehistoriallisten retkikuntien paremmin tunnettuun historiaan.

Tarkastelen tässä artikkelissa mittauspiirustusmatkoihin liittynyttä prosessia, jonka kuluessa puukirkkojen arvostus muuttui. Muutos kytkeytyi pyrkimyksiin kartoittaa, kirjoittaa ja julkaista suomalaisen rakennustaiteen historia, Muinaismuistoyhdistyksen taidehistoriallisiin retkikuntiin sekä Nyströmin toimintaan arkkitehtuurin opettajana ja rakennussuojelun vaikuttajana. Artikkelin aluksi käsittelen Nyströmin johtamien mittauspiirustusmatkojen tavoitteita, koska pidän niitä ratkaisevan tärkeinä hänen puukirkkotutkimustensa ymmärtämiselle. Sen jälkeen pureudun puukirkkojen arvostuksen muuttumiseen. Lopuksi tulkitsen Nyströmin puukirkkotutkimuksia säilyneiden lähteiden perusteella. Vaikka hän ei ehtinyt julkaista tutkimustensa tuloksia, ne ovat kuitenkin tavoitettavissa ainakin jossain määrin hänen julkaisemattomien luentokäsikirjoitustensa, kirjeenvaihtonsa ja opiskelijoidensa luentomuistiinpanojen kautta. Lisäksi niitä valaisee laaja piirustusmateriaali, jonka hän kokosi yhdessä opiskelijoidensa kanssa Teknilliseen korkeakouluun.

\section{Mittauspiirustusmatkat ja niiden tavoitteet}

Monet 1800-luvun ja 1900-luvun alun tutkijat uskoivat, että kansan ominaispiirteet ja ilmaisuvoima ilmenivät rakennuksissa ja esineissä. Kansan elinkelpoisuuden osoittaminen kuului tuolloin rakennusperinnön tutkimuksen tärkeimpiin tavoitteisiin. Erityisesti keskiaikaisten kivikirkkojen avulla tutkijat pyrkivät kertomaan Suomen köyhän kansan kuuluneen jo varhain eurooppalaisen sivistyksen piiriin. Eliel Aspelin kuului tutkijoihin, jotka kokivat tärkeäksi osoittaa, että suomalaisilla oli oma, kotoperäinen ja samalla kansainvälisesti vertailukelpoinen taide ja arkkitehtuu- 
ri. Hän julkaisi vuonna 1891 Suomen taiteen historian ensimmäisen yleisesityksen, joka kattoi myös arkkitehtuurin. ${ }^{10}$ Sitä valmistelleessaan Aspelin käytti Gustaf Nyströmiltä saamaansa mittauspiirustusmateriaalia Suomen keskiaikaisista kivikirkoista. Jouluna 1890 Nyström kirjoitti Pariisissa opintojaan täydentäneelle opiskelijalleen Usko Nyströmille:

Jag tycker om Aspelin, han söker att visa hvad vi sjalfva äga ... Nu skall han taga itu med vår äldsta arkitektur och har bedt mig om våra uppmätningar af de gamla kyrkorna. Dem skall han gerna få och mera till bara vi hinna. Ty, ehuru det går långsamt, har jag lofvat mig sjelf att så långt jag hinner, uppmäta de vördnadsvärda blad vår äldre kyrkokonst efterlemnat. ${ }^{\text {II }}$

[Pidän Aspelinista, hän pyrkii näyttämään mitä me itse omistamme. ... Nyt hän aikoo ottaa selvää vanhimmasta arkkitehtuuristamme ja on pyytänyt minulta mittauksiamme vanhoista kirkoista. Ne hän saa ja myös lisää, kunhan vain ehdimme. Vaikka työ edistyy hitaasti, olen luvannut itselleni, että niin pitkälle kuin vain ehdin, mittaan vanhimman kirkkotaiteemme jälkeensä jättämät kunnianarvoisat sivut.]

Gustaf Nyström oli vastikään aloittanut opiskelijoidensa kanssa kunnianhimoisen projektin, jonka päämääränä oli dokumentoida mittauspiirustuksin kaikki Suomen vanhat kirkot. Piirustukset sijoitettiin Polyteknillisen opiston (vuodesta 1908 lähtien Teknillisen korkeakoulun) arkistoon odottamaan näiden historian "kunnianarvoisten sivujen" julkaisemista arvoisellaan tavalla.

Polyteknillisen opiston arkkitehtiopiskelijoiden kotimaan kohteisiin suuntautuneet mittauspiirustusmatkat alkoivat pääsiäisenä 1889, jolloin kymmenkunta kolmannen vuosikurssin opiskelijaa mittasi ja piirsi Turun tuomiokirkkoa ja Maarian kirkkoa Nyströmin ja Onni Törnqvistin johdolla. Kohteet oli valittu paitsi arvonsa perusteella, myös siksi, että ne olivat rautateitse kätevästi saavutettavissa. ${ }^{12}$ Turun tuomiokirkko, jonka kappeleita parhaillaan kunnostettiin ja jonka kokonaisvaltaista restaurointia suunniteltiin, oli tärkein, suurikokoisin, kiireellisin ja samalla myös haasteellisin dokumentointikohde. ${ }^{13}$

Seuraavina vuosina arkkitehtiopiskelijat jatkoivat kirkkojen mittaamista ja piirtämistä pareittain, ja kohteina olivat aluksi Hattulan, Vanajan ja Pohjan keskiaikaiset kivikirkot. Vaikka Muinaismuistoyhdistyksen retkikunnat olivat vastikään dokumentoineet samat kirkot, sen retkillä ei ehditty käyttää aikaa rakennusten huolelliseen mittaamiseen. ${ }^{14}$ Polyteknillinen opisto ja sen seuraaja Teknillinen korkeakoulu järjestivät mittauspii- rustusmatkoja lukukausien aikana ja niiden päätteeksi, tosin 1890-luvulla, jolloin useat arkkitehtiopiskelijat osallistuivat Muinaismuistoyhdistyksen tutkimusretkille, yhteisten matkojen järjestämisessä näyttää olleen vuosien tauko. ${ }^{15}$ Kesäisin opiskelijat mittasivat ja piirsivät vanhoja rakennuksia eri puolilla Suomea. Polyteknillisen opiston muututtua Teknilliseksi korkeakouluksi Suomessa ei voinut valmistua arkkitehdiksi ilman mittauspiirustuksen laatimista merkittävästä kotimaisesta rakennuksesta. ${ }^{16}$

Mittauspiirustuksia kertyi vähitellen Teknillisen korkeakoulun arkistoon. ${ }^{17}$ Nyström kuitenkin valitti dokumentoinnin valtavaa määrää, hankalaa luonnetta ja varojen puutetta retkien toteuttamiseen. Keväällä 1911 Teknillisen korkeakoulun opettajaneuvosto myönsi 1250 markkaa vanhemman suomalaisen rakennustaiteen mittauspiirustusten laatimiseen, koskien erityisesti Turun tuomiokirkkoa. ${ }^{18}$ Seuraavana vuonna sama neuvosto myönsi Nyströmille 800 markkaa Gamla byggnader i Finland -julkaisusarjan toimituskuluihin. ${ }^{19}$ Puukirkkojen mittauspiirustuksia on säilynyt 1910-luvulta paljon, ja osa niistä on laadittu tätä julkaisusarjaa varten. Nyström toteutti syyskuussa 1913 Tek- 
nillisessä korkeakoulussa näyttelyn, jossa oli esillä noin viisikymmentä kirkko- ja linnapiirustusta. ${ }^{20}$ Piirustusarkistoa kartuttaakseen Teknillinen korkeakoulu jakoi rahapalkintoja ansiokkaille mittaajille ja osti Carolus Lindbergin vanhan suomalaisen rakennustaiteen piirustuskokoelman vuonna 1916. ${ }^{21}$ Tuolloin Arkitekten-lehti julkaisi Nyströmin johdolla laadittuja mittauspiirustuksia ja antoi tunnustusta tämän aloittamalle vanhojen rakennusten dokumentointityölle. ${ }^{22}$

Kotimaan rakennusmonumenttien mittaaminen ja piirtäminen liittyivät niin Suomessa kuin muuallakin Euroopassa Polyteknillisten oppilaitosten opetustoimintaan. ${ }^{23}$ Ulkomaisten kollegoidensa tavoin Nyström käytti mittauspiirustuksia opetusvälineinä. Niiden tarkoituksena oli johdattaa opiskelijat vanhojen rakennusten huolellisen havainnoinnin ja dokumentoinnin kautta arkkitehtuurin historiaan. Nyström yritti niiden avulla vakuuttaa tulevat arkkitehdit historian tutkimisen ja tuntemisen hyödyllisyydestä. Vanhat rakennukset tarjosivat hänen mukaansa loputtomasti esimerkkejä siitä, miten entisaikojen kollegat olivat ratkoneet parhailla mahdollisilla tavoilla erilaisia suunnitteluongelmia. ${ }^{24}$
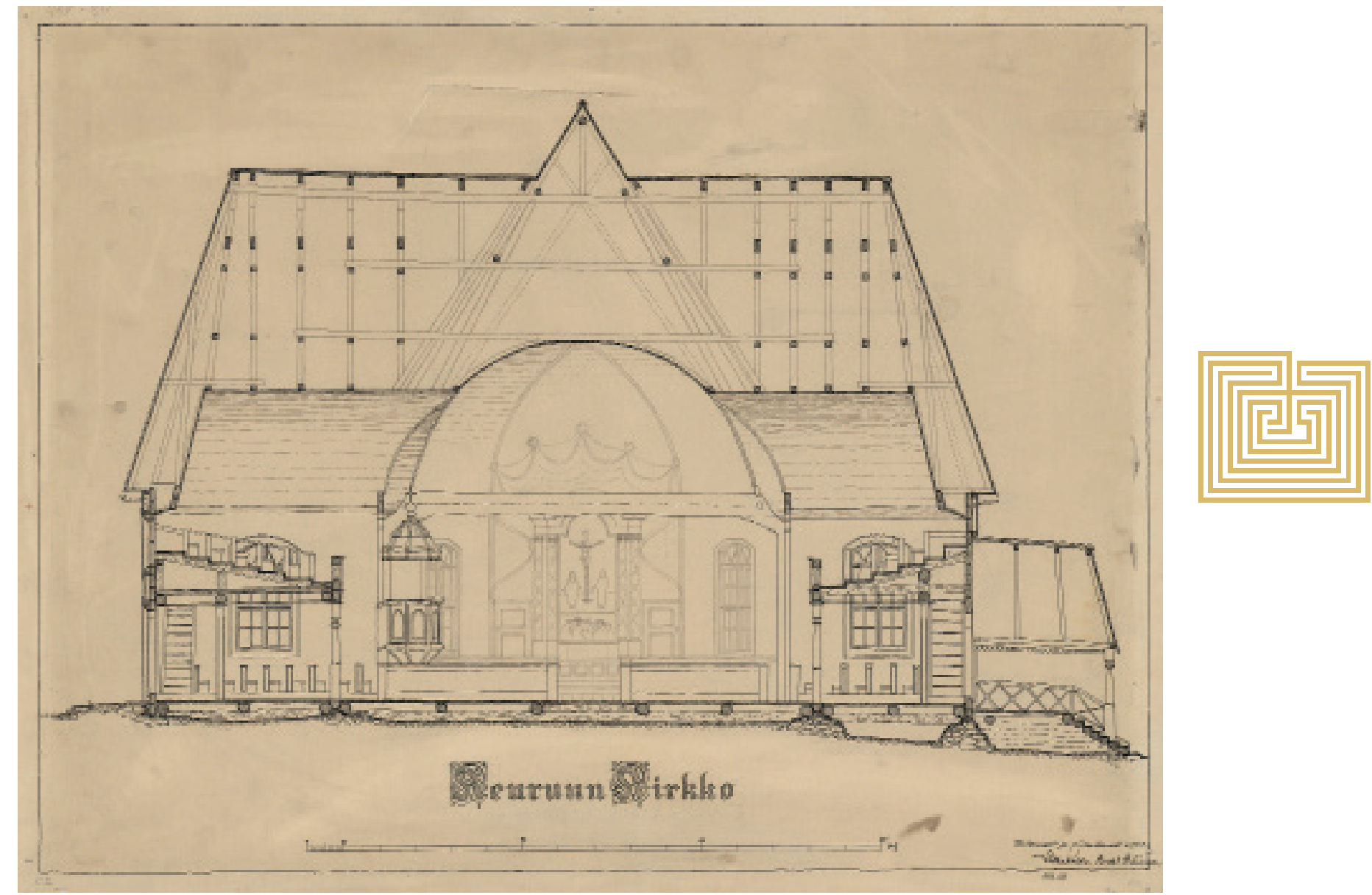

Kuva 1. Vilho Kolho ja Bertel Strömmer, mittauspiirustus Keuruun kirkosta, 1912. Tussi kartongille, 50 x 65 cm. Kuva: Aalto-yliopiston arkisto. 
Tanskan kuninkaallisen taideakatemian opiskelijoiden tekemät tarkat ja elegantisti toteutetut vanhojen rakennusten mittauspiirustukset tarjosivat esikuvan, johon Nyström opiskelijoineen pyrki. ${ }^{25}$ Tanskassa arkkitehtiopiskelijoiden perustama Föreningen af 3. December 1892 edisti kotimaan vanhan arkkitehtuurin tutkimusta ja julkaisi niiden tuloksia vuodesta 1894 lähtien. ${ }^{26}$ Rakennusperinnön dokumentoinnissa Tanska oli ihailtu esikuva myös ruotsalaisille arkkitehdeille. Ruotsissa arkkitehtiopiskelijat perustivat vuonna 1908 Arkitekturminnesföreningen-nimisen yhdistyksen dokumentointimatkojen järjestämiseen. Yhdistys julkaisi heti samana vuonna ensimmäisen osan sarjasta Svensk Arkitektur, jossa se esitteli matkojen tuloksia tekstein, piirustuksin ja valokuvin. ${ }^{27}$ Nyström hyödynsi sarjaa opetuksessaan. Kotimaan rakennusperinnön tutkimisen ja esittelemisen tavoite oli kaikkialla Pohjoismaissa sama; päämääränä oli luoda korkeatasoinen, kansallisesti leimallinen arkkitehtuuri, joka perustui kotimaiseen rakentamisen traditioon.

Tanskan uudessa arkkitehtuurissa oli Nyströmin ja monien muiden aikalaisten mukaan hyödynnetty onnistuneesti vanhaa ko- timaista tiiliarkkitehtuuria. Siellä paikallisen rakennusperinnön tutkiminen oli johtanut korkeatasoiseen ja omaperäiseen uuteen arkkitehtuuriin. Tämän Nyströmin usein toistaman käsityksen hän sai kirjattua Muinaistieteellisen toimikunnan pöytäkirjaan vuonna 1904:

Det är obestridligt att den nyare byggnadskonstens sundaste och mest beaktansvärda framsteg i de öfriga nordiska länderna nära sammanhänger med det noggranna studium man der egnat den äldre inhemska arkitekturen och som tillfört byggnadskonsten värdefull kunskap om det som i eget land pröfvats och befunnits godt. ${ }^{28}$

[On selvää, että uudemman rakennustaiteen terveimmät ja huomionarvoisimmat edistysaskeleet muissa Pohjoismaissa ovat läheisesti yhteydessä siellä harjoitettuun huolelliseen vanhemman kotimaisen arkkitehtuurin tutkimiseen, joka on tuonut rakennustaiteelle arvokasta tietoa siitä, mitä omassa maassa on kokeiltu ja hyväksi havaittu.]

Tanskaan suuntautuivat myös useat Nyströmin johtamat opintomatkat. ${ }^{29}$ "Varmaa laatua näkyy Tanskan arkkitehtuuri kulkevan puhtaalla kansallisella pohjalla luonnollisilla ja selvillä muodoilla, ei mitään ponnistelua, teennäistä", kirjoitti vaikutelmistaan kesällä 1903 Tanskan matkalle osallistunut arkkitehti Kauno S. Kallio. ${ }^{30}$ Pohjoismaisten kollegojen kanssa käydyt keskustelut rakennusperin- nöstä ja sen dokumentointitavoista johtivat myös piirustusten, kuvien ja julkaisujen vaihtoon. Tanskalainen kollega Hans J. Holm lähetti Nyströmille vuonna 1905 painetun piirustuskokoelman, joka esitteli vanhempaa pohjoismaista arkkitehtuuria. Nyström toivoi kiitoskirjeessään, että Suomessakin herättäisiin ymmärtämään pohjoismaisen rakennusperinnön arvo. ${ }^{31}$ Hän ihaili tanskalaisten tapaa säilyttää vanhaa kulttuuriaan ja heidän taitoaan rakentaa uutta sen varaan:

Det är vackert, vackert, att se huru Ni, Danske, bevara Eder gamla kultur - och huru ny, frisk och stark, växer fram derut. Huru djup sanning ligger det icke i Martin Nyrop's: "Af gammelt jern kan smedes ny Vaaben!" ${ }^{2}$

[Kaunista, niin kaunista on nähdä, kuinka Te tanskalaiset säilytätte vanhaa kulttuurianne - ja kuinka uusi, virkeä ja vahva kasvaa siitä. Kuinka syvä totuus piileekään Martin Nyropin motossa "Vanhasta raudasta voi takoa uusia aseita!"]

Nyströmin kunnianhimoisena päämääränä oli kattava tutkimus Suomen kirkkoarkkitehtuurista, puukirkot mukaan lukien. Näin laaja tutkimus- ja julkaisuhanke oli mahdollista toteuttaa vain yhteistyössä. Nyströmin opiskelija Otto-livari Meurman alkoi vuonna 1914 tehdä väitöskirjaa Suomen kirkkoarkkitehtuurista ja etenkin Carl Ludvig Engelin 
puukirkoista. ${ }^{33}$ Carolus Lindberg laati puolestaan Nyströmin ohjauksessa väitöskirjan tiilen käytöstä Suomen keskiaikaisissa kivikirkoissa. ${ }^{34}$ Molemmat olivat mitä ilmeisimmin tarkoitettu täydentämään Nyströmin suunnittelemaa näyttävästi kuvitettua julkaisua Suomen arkkitehtuurin historiasta.

\section{Puukirkot tutkimuskohteina}

Mittauspiirustusmatkojen alkaessa puukirkot eivät olleet ensisijaisesti tutkittavien kohteiden joukossa, mutta ne herättivät jo varhain huomiota. Kun Muinaismuistoyhdistys aloitti taidehistorialliset tutkimusretket Emil Nervanderin johdolla vuonna 1871, samana vuonna ilmestynyt yhdistyksen opaskirja kertoi niistä seuraavasti:

Tarkastusta ansaitsevat myöskin maamme vanhemmat puukirkot, jotka ulkomuotonsa puolesta lähinnä liittyvät götiläiseen taiteenmuotoon ehkä akkuna- ja ovilävet, rakennusaineen vuoksi, enim- $^{-}$ mästi ovat saaneet suorakulmaisen muodon. Noissa rakennuksissa on huomattava sisäkatto, joka joskus tynnyriholvin muodossa peittää katonkannattimet. Myöskin pienemmät koristavaiset osat katon-harjalla, akkunoiden äärillä sekä veistokset ja raudoitukset ovilla ansaitsevat usein kuvaamista. ${ }^{35}$

Vaikka Muinaismuistoyhdistyksen tutkimusretkien osallistujat dokumentoivat puukirkkoja ensimmäisestä retkestä lähtien, vielä

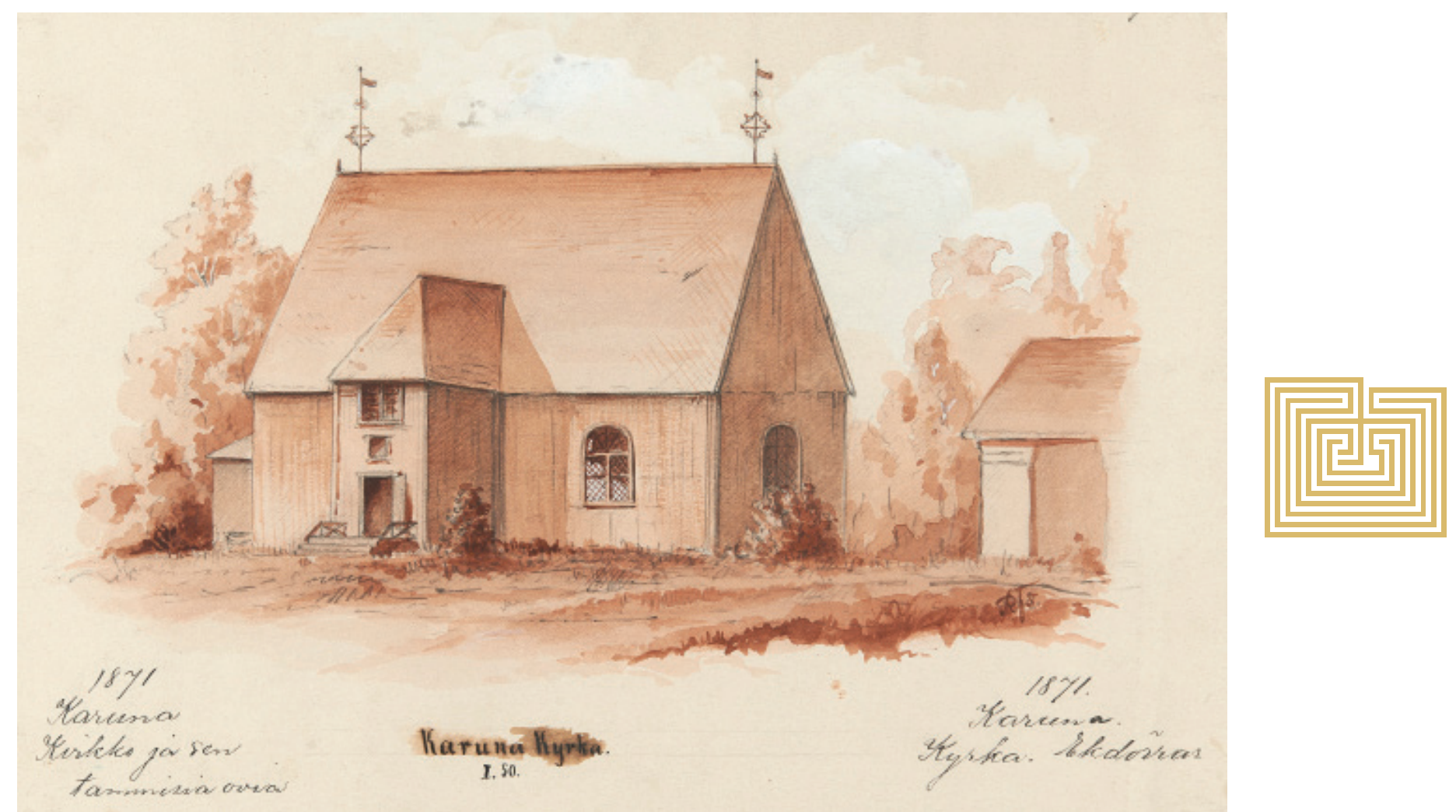

1890-luvun alkupuolella tutkijat eivät nähneet uuden ajan kirkkoarkkitehtuurissa keskiaikaisiin verrattavia arvoja. Vuonna 1891 Eliel Aspelin luonnehti 1700-luvun puukirkkoja seuraavasti: "sen mukaan mitä tunnetaan ei näillä rakennuksilla ylipäätään ole huomattavaa taiteellista arvoa". Tiedostaen, että Tukholman yli-intendentinviraston arkkitehdit olivat hyväksyneet, elleivät jopa laati-
Kuva 2. Reinhold Fabritius, Karunan kirkko, Muinaismuistoyhdistyksen ensimmäinen taidehistoriallinen retkikunta 1871. Vesiväri ja lyijykynä, 18 x $27 \mathrm{~cm}$. Kuva: Historian kuvakokoelma, Museovirasto. 
neet niiden piirustukset, hän kuitenkin lisäsi: "on kyllä mahdollista että maalaiskirkoissamme voisi olla yhtä ja toista arvokkaampaakin, etupäässä suhteiden kauneuteen nähden, mutta sen seikan arvostelemiseksi ovat tarpeelliset tutkimukset tekemättä." ${ }^{36}$ Aspelin saattoi toistaa julkaisuaan varten konsultoimansa Nyströmin ajatuksia. Puukirkkojen "tarpeelliset tutkimukset" olivat nimittäin juuri alkamassa.

Puukirkkojen arvonnousu liittyi kasvavaan kiinnostukseen kansanrakennuksia kohtaan. Vuoden 1892 kesällä Muinaismuistoyhdistyksen retkikuntaan osallistuneet arkkitehdit Selim A. Lindqvist, John Stolpe ja arkkitehtiopiskelija Lars Sonck piirsivät runsain määrin talonpoikien rakennuksia hirsisalvoksineen. Aiempien tutkimusretkien tapaan he laativat retkiohjelman mukaisesti myös puukirkoista pohjapiirustukset ja valokuvasivat tai piirsivät ne ulkoapäin. Retkikunnan matkustaessa Tampereelta höyrylaivalla Virroille, Ruovedelle ja Kuruun niiden puukirkot olivat Emil Nervanderin mukaan pettymys. Poikkeuksena oli kuitenkin Kärkölän kirkko, jonka arkkitehtuuri teki Nervanderiin vaikutuksen. Nervander ja kirkkoa dokumentoinut Lindqvist kohdistivat tuolloin huomion van- han puukirkon arkkitehtuurin esteettiseen arvoon. ${ }^{27}$

Kansanrakennukset innostivat tuolloin taiteilijoita, arkkitehteja ja tutkijoita. Vuonna 1894 arkkitehti Vilho Penttilä julkaisi piirustuksiaan eteläsuomalaisista luhtiaitoista, ja Suomen Käsityön Ystävät julkaisi ensimmäisen suomalaista tyyliä etsineen huonekalukilpailun tulokset. Saman vuoden kesällä polyteekkari Yrjö Blomstedt ja arkkitehti Victor Sucksdorff toteuttivat laajan tutkimusmatkansa Karjalaan, jonka aikana he keskittyivät kansanrakennusten ja esineellisen kulttuuriperinnön dokumentointiin. ${ }^{38}$ Kaksi vuotta myöhemmin Sucksdorff, Armas Lindgren ja Axel Wikström muodostivat Emil Nervanderin johtaman Muinaismuistoyhdistyksen Pohjanmaan-retkikunnan. Kuten Leena Valkeapää on osoittanut, kesän 1896 retken tärkeimpänä tarkoituksena oli pelastaa dokumentoiden seudun huonokuntoisten ja jopa purettavien kirkkojen Michael Toppeliuksen ja muut "Oulun koulun" maalaukset. Retkikunta piirsi ja valokuvasi ahkerasti seudun puukirkkoja, mutta mikään ei osoita heidän kiinnostuneen hirsistä salvotuista tukipilareista tai muista rakenteista. Pohjanmaan puukirkot näyttivät ulospäin vaatimattomilta,

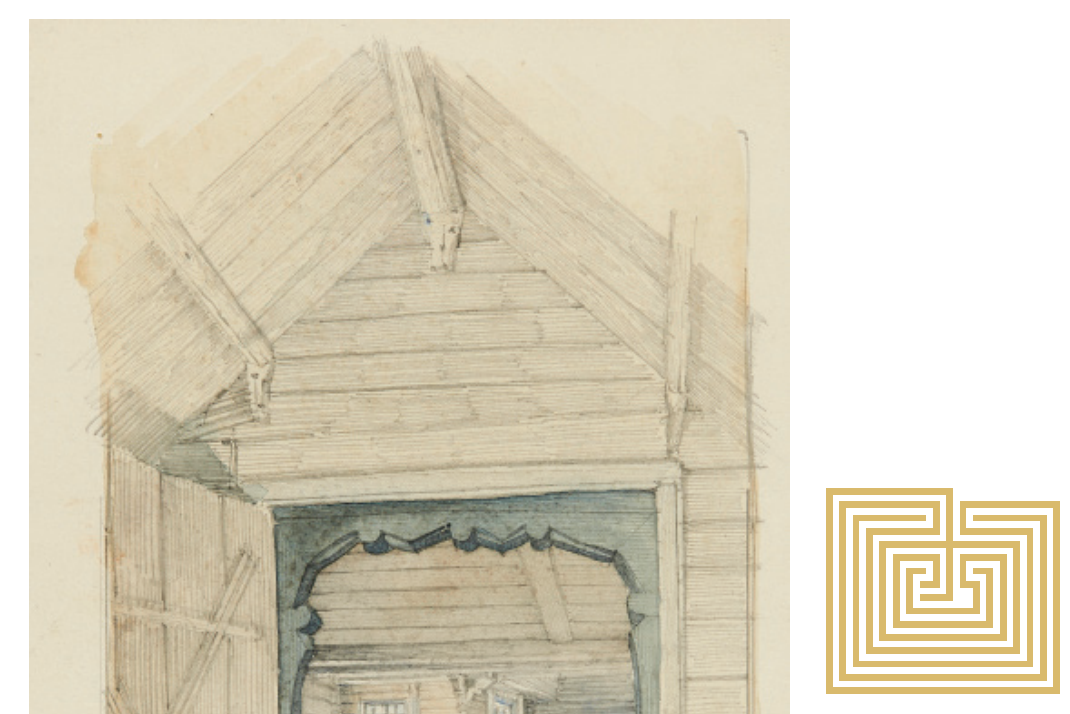
oviaukko ja interiööri, Muinaismuistoyhdistyksen viides taidehistoriallinen retkikunta 1892. Sekatekniikka, $28 \times 19$ cm. Kuva: Historian kuvakokoelma, Museovirasto. 
eivätkä ne Nervanderin sanoin "ensi silmäyksellä lupaa suurtakaan korvausta taidehistorioitsijalle nähdystä vaivasta". ${ }^{39}$ Päähuomio oli maalauksissa, mistä kertoo myös Armas Lindgrenin kuuluisa akvarelli Saloisten kirkon interiööristä eli "Suomen San Marcosta", kuten retkikunnan tuloksia esitelleen näyttelyn anonyymi vierailija tämän pienen maalaiskirkon tunnetusti nimesi. ${ }^{40}$

Puukirkkoarkkitehtuurin tutkimisen varhaisvaiheet kiinnittyivät paitsi kansanrakennusten dokumentointiin, myös kirkkojen purku-ja korjaushankkeisiin. Gustaf Nyströmistä tuli Muinaismuistoyhdistyksen ehdotuksesta Muinaistieteellisen toimikunnan jäsen ja ensimmäinen arkkitehtuurin ammattilaisasiantuntija vuoden 1897 alusta lähtien. ${ }^{41}$ Toimikunnan tehtäviin kuului lausuntojen antaminen kunnostettavista tai purettavista julkisista rakennuksista ja kirkoista. Aiemmin toimikunta oli tukeutunut lähinnä Emil Nervanderiin kotimaan vanhempaa taidetta ja arkkitehtuuria koskevissa kysymyksissä. ${ }^{42}$ Kirkkojen purkamisen ja korjausten lisääntyessä niiden tutkimisen ja dokumentoinnin tarve kasvoi. Nyström teki tutkimusmatkoja toimikunnan määräyksestä, mutta omien sanojensa mukaan tärkeimmät ja pisimmät

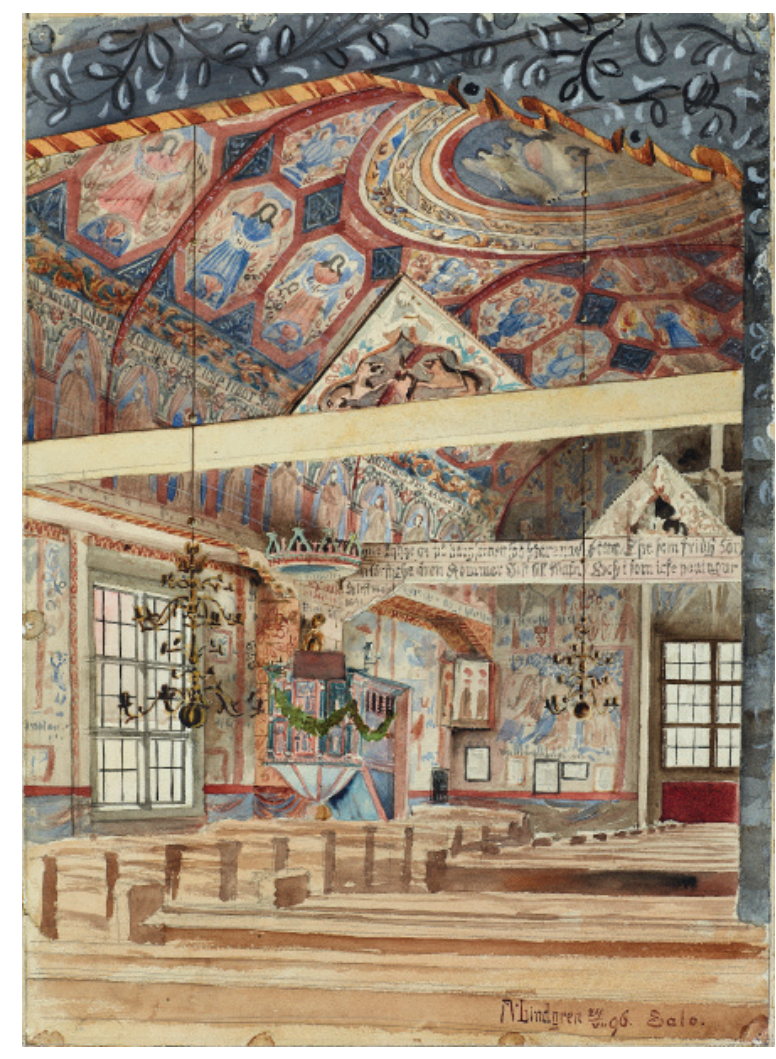

Kuva 4. Armas Lindgren, Saloisten kirkon interiööri, Muinaismuistoyhdistyksen kuudes taidehistoriallinen retkikunta 1896. Sekatekniikka, 39 × 28 cm. Kuva: Historian kuvakokoelma, Museovirasto. matkat hän teki omasta aloitteestaan. Välillä mukana oli valtionarkeologi J. R. Aspelin, mutta kaikkein antoisimpia olivat hänen omien sanojensa mukaan ne, jotka hän teki joko yksin tai oppilaidensa kanssa. ${ }^{43}$

Nyströmin oppilaat dokumentoivat uuden ajan puukirkkoarkkitehtuuria 1900-luvun alkuvuosista lähtien. Kesällä 1905 vastavalmistunut arkkitehti Toivo Aukusti Paatola (entinen Packalin) sekä arkkitehtiopiskelijat Paavo Uotila ja (Jalo Oiva) Antti Viljanen kiersivät Hämäläis-Osakunnan lähettäminä dokumentoimassa kotiseutunsa Hämeen rakennusperintöä. ${ }^{44}$ Paatola ja Uotila työskentelivät opintojensa aikana Nyströmin toimistossa. ${ }^{45} \mathrm{He}$ järjestivät retkien tuloksista näyttelyn, jossa oli esillä piirustuksia, maalauksia ja valokuvia alueen vanhoista kirkoista. Hufvudstadsbladetin mukaan näyttelyssä esitellyt Keuruun ja Petäjäveden kirkot olivat "erittäin kiinnostavia joka suhteessa" ("ytterst intressanta i alla afseenden.") ${ }^{46}$ Opiskelijoiden ja nuorten arkkitehtien kesäiset dokumentointiretket johtuivat paitsi kansanrakentamisen ja kotiseutuhistorian muodikkuudesta, myös siitä, että kotimaan arkkitehtuurin historia oli tärkeä osa tulevien arkkitehtien koulutusohjelmaa. Puukirkoista 


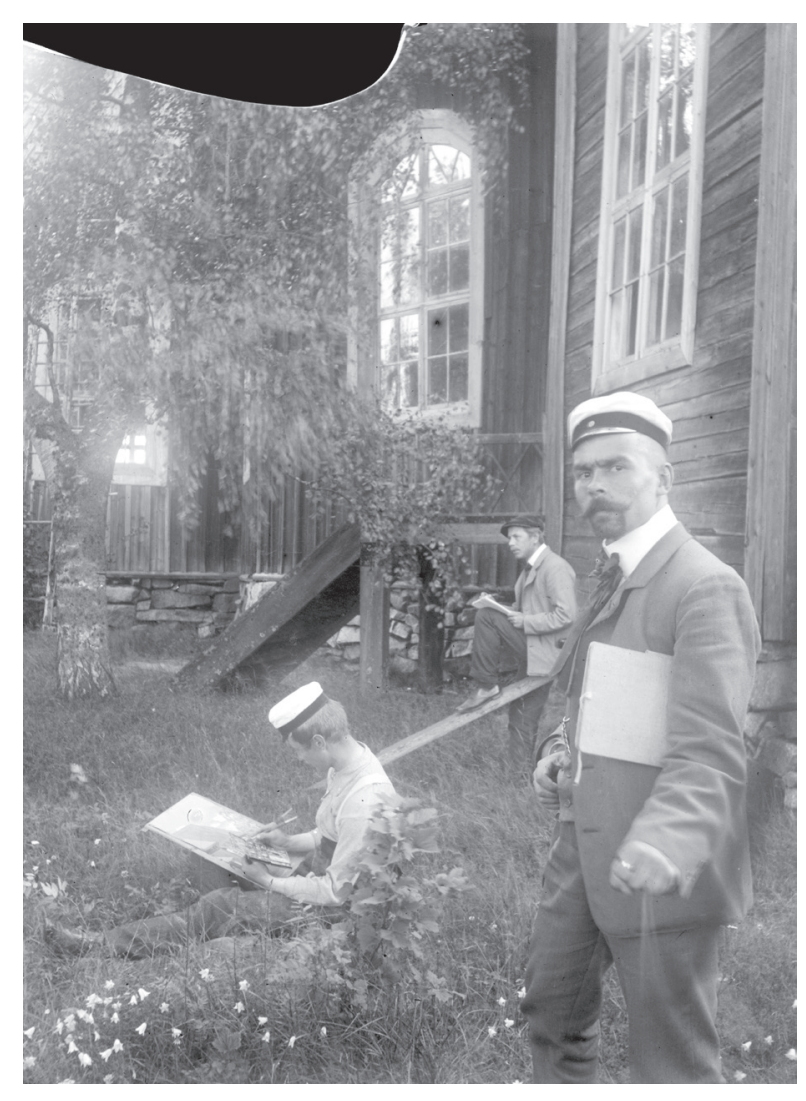

Kuva 5. Toivo Paatola, Paavo Uotila ja Antti Viljanen kirkkoretkellä, valokuva 1905ר1906. Kuva: Museokeskus Vapriikki. oli tullut arkkitehtien piirustusmatkojen kohteita ja kiinnostavaa rakennusperintöä, jota esiteltiin näyttelyin myös laajalle yleisölle.

\section{Kärkölä, Saloinen ja puukirkkojen arvostus}

Puukirkkoarkkitehtuurin yleisessä arvostuksessa tapahtui selvä ja hämmästyttävän nopea muutos 1900-luvun vaihteessa. Vielä vuonna 1897 monet asiantuntijat pitivät Suomen 1600-ja 1700-lukujen kirkkoarkkitehtuuria mitättömänä. J. J. Tikkanen kirjoitti silloin Muinaismuistoyhdistyksen edellisen kesän retkikunnan tuloksia esittelevästä näyttelystä: "Kuten yleensäkin maalaiskirkkomme 1600- ja 1700-luvuilta, ovat Pohjois-Pohjanmaan saman ajan kirkot hyvin vähäpätöisiä ja niiden arkkitehtuuri erittäin köyhää niin ulkoa kuin sisältäkin." ${ }^{\text {"77 }}$ Ainoastaan Tornion kirkon interiööri oli Tikkasen mielestä poikkeus. Sitä hän kuvaili sanoilla "originelli, rikas ja pittoreski". ${ }^{48}$ Seuraavien vuosien aikana suhtautuminen puukirkkojen arkkitehtuuriin muuttui täysin, johtuen niiden aiempaa tarkemmasta tutkimisesta ja uudesta statuksesta omaperäisenä rakennusperintönä. Vierailtuaan Saloisten kirkossa kesällä 1899 Gustaf Nyström ymmärsi sen salvottujen tu- kipilarien, kattorakenteen ja myös esteettisten arvojen erityisyyden. Hän välitti löytönsä nopeasti Muinaistieteellisen toimikunnan ja Muinaismuistoyhdistyksen asiantuntijoille sekä opiskelijoilleen. Asialla oli kiire, koska monet puukirkot ja niiden maalaukset olivat välittömässä tuhoutumisvaarassa.

Puukirkkojen ja tapuleiden purkaminen oli tuolloin yleistä, ja näin tapahtui muiden muassa Kärkölän puukirkolle. Kärkölän seurakunta anoi alkuvuonna 1897 Muinaistieteelliseltä toimikunnalta suostumusta uuden tiilikirkon myötä käyttämättömäksi jääneen, vuonna 1745 valmistuneen puukirkon purkamiseen ja sen hirsien käyttämiseen uutta kansakoulua varten. Kuten jo aiemmin kävi ilmi, kirkko oli dokumentoitu Muinaismuistoyhdistyksen tutkimusretkellä 1892. Toimikunnan uusi jäsen Nyström ei työmatkan vuoksi päässyt osallistumaan kokoukseen, jossa Kärkölän kirkosta keskusteltiin. Toimikunnan sihteeri J. R. Aspelin kirjoitti pöytäkirjaan, että jos Nyström katsoisi sen aiheelliseksi, kirkossa oli suoritettava uudet tutkimukset. Nyströmin ja Nervanderin kehotuksesta tutkimusmatkalle lähti kirkkojen taitavana dokumentoijana kunnostautunut Armas Lindgren. Hänen 25.8.1897 päivättyjen akvarelliensa 
ja piirustustensa valmistuttua valtionarkeologi Aspelin antoi luvan kirkon purkamiseen. ${ }^{49}$

Kirjeestä, jossa Nyström esitti Muinaistieteelliselle toimikunnalle "nöyrän ehdotuksensa" Kärkölän kirkon dokumentoinnista, välittyy paitsi hänen käsityksensä Suomen puukirkoista olennaisena osana Suomen arkkitehtuurin vielä kirjoittamatonta historiaa, myös hänen pyrkimyksensä muuttaa toimikunnan siihen asti suosimaa vanhojen rakennusten dokumentointitapaa aiempaa tarkemmaksi. Hän pyysi, että valokuvien ja perspektiiviakvarellien lisäksi Kärkölän kirkosta laadittaisiin pohjapiirustus ja myös leikkaus- ja julkisivupiirustukset tietyssä mittakaavassa. Nyströmin mukaan nimenomaan rakenteelliset ominaisuudet olivat tärkeitä puukirkoissa, kuten ne olivat Norjan sauvakirkoissakin. ${ }^{50}$ Hän kohdisti huomion kirkon arkkitehtuuriin, jonka arvot voisivat huolellisella dokumentoinnilla välittyä tuleville sukupolville.

Käänteentekeviä sekä Nyströmin tutkimuksille että puukirkkojen arvostukselle laajemmin olivat korjaukset ja tutkimukset Saloisten kirkossa. Huonokuntoista kirkkoa korjattiin 1880-luvulla, jolloin paikkakunnalla kinasteltiin siitä, tuliko maalaukset poistaa ja

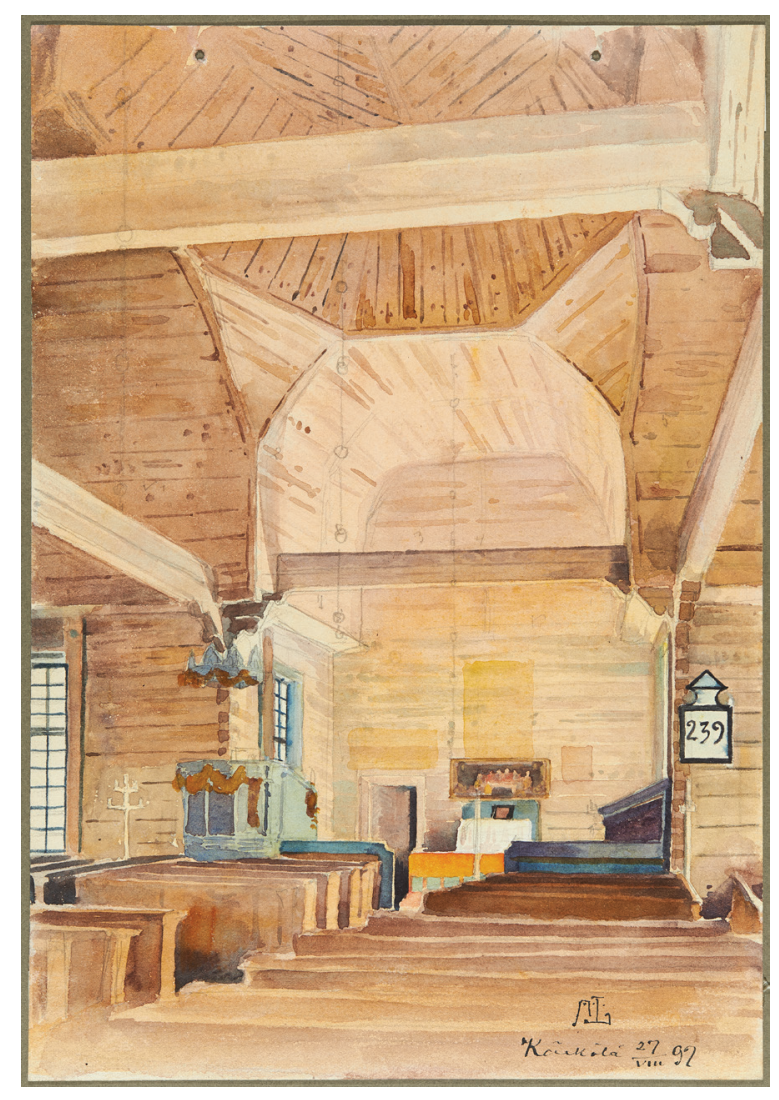

Kuva 6. Armas Lindgren, Kärkölän kirkon interiööri, 1897. Vesiväri ja lyijykynä, 25 x $18 \mathrm{~cm}$. Kuva: Historian kuvakokoelma, Museovirasto. siirtää museoon vai säilyttää alkuperäisellä paikallaan. Kuulopuheet kertoivat, että erään arkkitehdin mukaan maalauksilla ei ollut "mitään kaunotieteellistä arvoa, eikä myös mitään hengellisyyttä korottavaa vaikutusta". ${ }^{51}$ Maalaukset jäivät tuolloin paikoilleen, vaikka useat pitivät selvänä, että "sopimattomat" maalaukset vielä peitettäisiin. Paikkakunnalla vieraillut Eliel Aspelin vaati maalausten tutkimista ja kuvausta ennen peittämistä. Vaikka Aspelinin mukaan maalausten taiteellinen taso oli alhainen, niillä oli kuitenkin kulttuurihistoriallista arvoa. ${ }^{52}$

Saloisten kirkon arvon määrittäminen tuli jälleen ajankohtaiseksi keväällä 1896 kirkon korjauksen yhteydessä. Yleisten rakennusten ylihallitus antoi Oulun lääninarkkitehti W. A. Tötterströmille tehtäväksi laatia kirkon korjaussuunnitelmat. ${ }^{53}$ Muinaistieteellinen toimikunta valtuutti Emil Nervanderin valvomaan toimikunnan etua paikkakunnalla. Nervanderin johtama Muinaismuistoyhdistyksen retkikunta dokumentoi samana kesänä kirkkoa ja erityisesti sen maalauksia, joiden se pelkäsi pian tuhoutuvan. ${ }^{54}$ Korjaushankkeen käynnistyttyä sanomalehdissä uutisoitiin, että Saloisten kirkko aiotaan hajottaa ja rakentaa uudelleen. Valtionarkeologi Aspelin 
lähetti kysymysryöpyn paikkakunnan kirkkoherranvirastolle "vanhoista maalauksistaan mainion kirkon" hajottamishuhuista: kuka oli tehnyt päätöksen, kuinka pitkälle asiaa oli ajateltu, missä olivat piirustukset ja eikö kirkkoa voisi korjata hajottamatta? ${ }^{55}$ Vastauskirjeessä vakuutettiin, ettei kirkkoa hajotettaisi: "Sanomalehdet näkyvät aina tietävän enemmän asiasta kuin tarpeellista olisikaan."

Tötterströmin korjaussuunnitelma tähtäsi kirkon lämmityksen parantamiseen. Sen mukaan kirkon vanha sisäkatto olisi purettu ja korvattu uudella. Laudat, joissa 1600-luvun maalaukset olivat, oli tarkoitus käyttää lattian korottamiseen; ne olisi sijoitettu uuden lattian alle. Kuultuaan tästä Nyström kauhistui. Kirjeessään ruotsalaiskollegalleen Agi Lindegrenille hän kertoi suuttuneensa ja kironneensa Tötterströmin suunnitelman hyväksyneille Yleisten rakennusten ylihallituksen arkkitehdeille niin, "että rikinkatku haisi joka nurkassa". ${ }^{57}$ Tuolloin vielä yleensä ajateltiin, että arvokkainta Saloisten kirkossa olivat sen värikylläiset maalaukset. Korostaen maalausten merkittävyyttä Muinaistieteellinen toimikunta ehdotti, että Yleisten rakennusten ylihallitus laatisi uuden, maalaukset säilyttävän ja niiden tyyliin sopivan korjaus- suunnitelman. Saloisten kirkko kuului sen mukaan taidehistoriallisessa mielessä maan kiinnostavimpiin kirkkoihin, ja Tötterströmin korjaussuunnitelma oli karkeinta mahdollista vandalismia. ${ }^{58}$

Nyström lähetti Tötterströmille kohteliaan kirjeen ja pyysi yhteistyötä tässä "Suomen arkkitehtuurille erittäin merkittävässä ja kiinnostavassa asiassa". Saloisten kirkko kuului Nyströmin mukaan Suomen arvokkaimpiin niin rakenteeltaan kuin maalauksiltaan. Hän pyysi lääninarkkitehtia tekemään kaikkensa, jotta sisäkatto maalauksineen säilyisi. Samalla hän vetosi myös Hailuodon kirkon ja sen maalausten säilymisen puolesta, joita uhkasi sama kohtalo. ${ }^{59}$ Lääninarkkitehti Tötterström ja Yleisten rakennusten ylihallitus pitäytyivät kuitenkin kannassaan. Heidän mukaansa kirkkoa ei ollut mahdollista korjata maalaukset säilyttäen. Nervander kehotti valtionarkeologi Aspelinia kieltämään seurakuntaa hajottamasta kirkkoa ennen kuin se oli dokumentoitu tarkemmin ja ehdotti katon maalausten siirtämistä museokokoelmiin Helsinkiin. ${ }^{60}$ Nyström tarjoutui matkustamaan paikan päälle tutkimaan, jos kirkon voisi sittenkin korjata maalaukset säilyttäen. ${ }^{61}$
Nyström matkusti Saloisiin kesän 1899 alkaessa yhdessä arkkitehtiveljensä Alexander Nyströmin kanssa. Tuolloin veljekset alkoivat tutkia puukirkon erikoisia rakenteita, muun muassa kattotuoleja ja sen seinien onttoja, salvottuja tukipilareita. Heidän matkansa jälkeen Muinaistieteellinen toimikunta esitti uusien korjaussuunnitelmien laatimista maalauskoristelut säilyttäen. ${ }^{62}$ Tämän seurauksena Victor Sucksdorff laati korjaussuunnitelman, jonka toimikunta Nyströmin lausuntoa seuraten hyväksyi täysin. ${ }^{63}$

Keskustelu Saloisten kirkosta johti vuosien 1899 ja 1900 aikana laajaan kiinnostukseen puukirkkoarkkitehtuuria kohtaan. Axel Gallén piirsi vuonna 1900 Pihlajaveden puukirkon hirsirakenteita. ${ }^{64}$ Samoihin aikoihin virisi keskustelu Saloisten kirkon siirtämisestä Kansallismuseon viereiseen ulkomuseoon Helsinkiin. ${ }^{65}$ Nyström kysyi kirjeitse Sucksdorffilta tämän näkemystä kirkon siirtämisestä ja sen riskeistä maalauksille. Sucksdorffin mukaan maalausten siirtäminen oli mahdollista, mutta koko rakennuksen siirtäminen ei ollut hänestä hyvä idea. Sitä vastoin hän ehdotti museohuonetta, jonka seiniä ja kattoa koristivat Saloisten kirkon maalaukset. Sucksdorff vertasi museohuonetta Nürnber- 


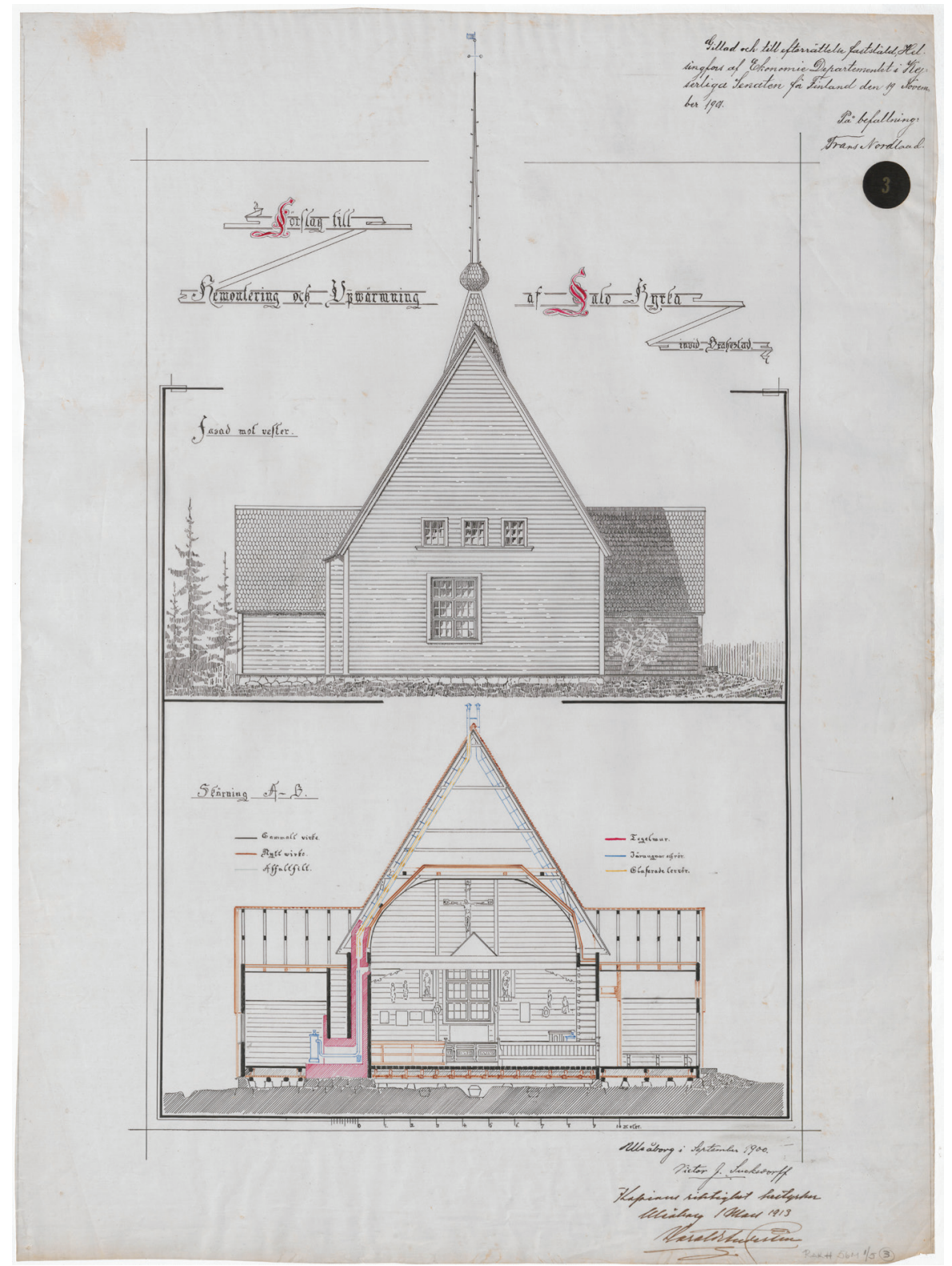

Kuva 7. Kopio Victor Sucksdorffin Saloisten kirkon korjaussuunnitelmasta 1900. Rakennushallituksen piirustusarkisto, Kansallisarkisto.

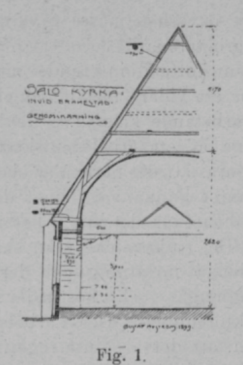

mycket energisk samt så anordnad, att större dele af sidoskjutningen upphâtves. För upptagande af

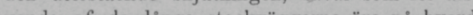
och genom sin rika omvexling förläna kyrkan ett langgsidan upprorda ett slags högst egendomliga konpá sádant sätt, att halfva kontreforten faller utanfổr och den andra halltten innanför väggen. FH relsevis mindre betydelse, dis de delvis sente

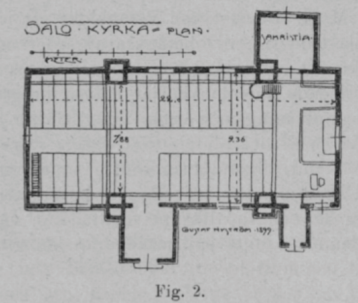

hänga med de öfriga utbyggnaderna och dessutom sluta stumt under vattentaket. I det inre däremot bilda de ett hogst verksamt motiv, som pá det in-

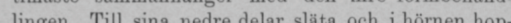
huggna med alhäringsknutar, öfvergả kontreforternas stockväggar upptill i starkt framspringande kon. soler med rikt utskurna ändar. Dessa konsoler uppbära tvá system kraftiga bjalkar, det ena lopande

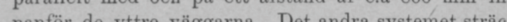
ankringar väggarna emellan.

De först nämnda bjălkarna, hvilka löpa paral. lelt med yttre väggarna, bilda jâmte dessa ett bredt; kraftigt underlag for takstolarna. Ifrán dem hojer sig det inre taloti $\mathrm{s}$. kyrkosalen ett kraftigt fördeladt rum med goda måttligt höga proportioner.

Takhvalfvet är nederst prydt med en arkadlik Sáväl till väggar som tak är detta rum prydt rä̀cka af málade nischer med inställda profeter ook
med mâlade bilder, hvilka fullständigt utfylla ytorna
apostlar. Iklädda full ornat och fôrsedda med alla

Kuva 8. Gustaf Nyström, sivu artikkelista "Salo kyrka", Tekniska Föreningens i Finland Förhandlingar 1902.

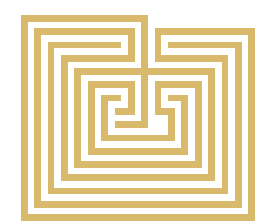

У)ahiti 1/2020 | Artikkelit | Ripatti: Gustaf Nyström ja Suomen puukirkkojen ainutlaatuisuus 
gin germaaniseen kansallismuseoon sillä erotuksella, että Helsingissä Saloisten kirkon maalaukset olisivat "aidot". ${ }^{66}$ Nyström ei puoltanut kirkon siirtämistä, koska maalaukset olisivat sen aikana väistämättä kärsineet. Muinaistieteellinen toimikunta seurasi hänen näkemystään. ${ }^{67}$ Saloisten sijaan Seurasaaren ulkomuseoon siirrettiin lopulta vuonna 1912 Karunan kirkko.

\section{Nyströmin puukirkkotutkimukset}

Nyström esitteli Saloisten kirkkoa Tekniska föreningen i Finlandin kokouksessa joulukuussa 1901 ja seuraavana vuonna hän julkaisi siitä artikkelin saman yhdistyksen lehdessä. Artikkelissa hän selosti sidehirsien kekseliästä rakennetta lautaholvin yläpuolella. Niin sidehirret kuin seinien omalaatuiset, ontot tukipilarit ("ett slags högst egendomliga kontreforter") kuuluivat olennaisina osina kirkon erikoiseen rakenteeseen. Nyström kohdisti huomion erityisesti puukirkon rakenteellisiin ominaisuuksiin, kattorakenteen, sidehirsien ja tukipilareiden kokonaisuuteen. Vasta niiden jälkeen hän siirtyi käsittelemään kirkon runsaita maalauksia. Hän pyrki osoittamaan, että Saloisten kirkko kuului niin rakenteeltaan kuin sisätilojen koristeluiltaan maan arvokkaimpiin ja kiinnostavimpiin rakennuksiin. ${ }^{68}$ Hän vertasi Saloisten kirkkoa maalauksineen Pohjois-Italian kirkkoihin:

Till sin anordning påminner denna dekorering om de härligheter som möta ögat nere i södern der kyr kornas tak, särskildt i norditalien, ofta äro bildade af enkla bräder på samma sätt som uti vår lilla kyr ka här uppe vid polecirkeln - men genom målarens pensel höjts till konstverk som stå på höjden af sin tids skapareförmåga. ${ }^{69}$

[Jäsentelyltään nämä koristelut muistuttavat ihanuuksia joita voi nähdä etelässä, missä kirkkojen $\mathrm{ka}^{-}$ tot, erityisesti Pohjois-Italiassa, on usein muodostettu yksinkertaisista laudoista samaan tapaan kuin pienessä kirkossamme täällä pohjoisessa napapiirin tuntumassa - mutta taiteilijan pensselin kautta kohotettuna aikansa luomiskyvyn huipulle.]

Nyström rinnasti periferisen Saloisten kirkon taiteen eteläisen keskuksen eli Italian kirkkoihin esittäen ne yhtä arvokkaina ja loisteliaina taideteoksina. Nyströmin kirjallisissa kuvauksissa Saloisten kirkosta toistuvat kirkon pohjoinen sijainti ja näennäinen vaatimattomuus sekä se, että sisätiloissa vierailijaa odotti yllätys: kirkon arkkitehtuuri ja maalaukset muodostivat omintakeisen ja esteettisesti erittäin korkeatasoisen kokonaisuuden. Pohjoismaisten arkkitehtien kokouksessa Kööpenhaminassa vuonna 1903 ja myös kirjeitse Nyström kuvaili piirroksin ja valokuvin tätä "melkein napapiirillä" ja kovin köyhällä alueella sijainnutta kirkkoa tanskalaiselle arkkitehti Herman Storckille. Maalausten ainutlaatuisuuden lisäksi Nyström korosti kirkon arkkitehtonisia arvoja. Hän johdatti jälleen huomion kirkon salvottuihin tukipilareihin ja sidehirsiin. ${ }^{70}$ 1900-luvun alkuvuosina Nyström näki Suomen puukirkkoarkkitehtuurin kansainvälisesti kiinnostavana rakennusperintönä, jonka erityispiirteitä saattoi ylpeänä esitellä pohjoismaisille kollegoille.

Nyström oli 1900-luvun alkuvuosina selvästi innoissaan puukirkoista, ja etenkin 1910-luvulla myös hänen opiskelijansa mittasivat ja piirsivät niitä aktiivisesti. Keväällä 1916 hän kirjoitti veljelleen, että puukirkkotutkimus, jonka he yhdessä olivat aloittaneet vuosisadan vaihteessa, oli nyt tullut eräänlaiseen päätökseen. Tuolloin oli juuri valmistunut esitelmä, jonka Nyström piti seuraavana päivänä (15.3.1916) Arkkitehtiklubilla. Runsain piirustuksin ja dioin elävöitetty esitelmä käsitteli hänen kauan pohtimaansa puukirkkorakennusten ideaa. ${ }^{71}$ Kirjeessään Nyström kertoi vihdoin selvittäneensä asian juurta jaksain. Vain joitakin kirkkoja lukuun ottamatta, joiden esikuva oli Ruotsissa, Suomen 
puukirkot olivat hänen mukaansa rakenteellisesti aivan oma ja ainutlaatuinen ryhmänsä. Hän viittasi Lorentz Dietrichsonin kuuluisaan kirjaan sauvakirkoista (De Norske stavkirker, 1892):

Det känns som då Dietrichson fick sin norska stavkyrka klar, och jag tycker, nej vet, att vi finska byggmästare kunna vara lika glada och stolta öfver våra förfäders byggnadskonst, som Norrmännen öfver $\sin .^{72}$

[Tuntuu samalta kuin Dietrichsonin saadessa norjalaiset sauvakirkkonsa valmiiksi, ja ajattelen, ei vaan tiedän, että me suomalaiset rakennusmestarit voimme olla yhtä iloisia ja ylpeitä esi-isiemme rakennustaiteesta kuin norjalaiset omastaan.]

Kirjeestä ilmenee tutkijan innostus ja myös helpottunut mieliala pitkäaikaisen työn valmistuttua. Nyström oli vakuuttunut, että vastaavia rakenteellisia ratkaisuja ei esiintynyt missään muualla. Suomen tukipilarikirkot olivat hänen mukaansa ainutlaatuisia, Norjan sauvakirkkoihin verrattavia arkkitehtuurin historian mestariteoksia.

Nyströmin esitelmä ei ole säilynyt, mutta hän esitteli tutkimustaan myös muissa yhteyksissä. Puolitoista vuotta aiemmin, syksyllä 1914, hän piti luentosarjan Suomen puukirkoista Teknillisessä korkeakoulussa. ${ }^{73}$ Joulukuussa 1914 hän esitelmöi aiheesta myös
Arkkitehtiklubilla. ${ }^{74}$ Luennoissaan hän pyrki nostamaan vanhojen puukirkkojen arvostusta ja valitti niiden purkamista ilman mittauksia uusien kirkkojen valmistuttua. Nyström vetosi tuleviin arkkitehteihin: olivatko vanhat puukirkot tuomittu häviämään vai olivatko ne suojelemisen arvoisia? Eivätkö arkkitehdit voineet vaikuttaa siihen, että nämä vanhat ja arvokkaat rakennukset säilyivät? ${ }^{75}$ Opiskelija Salme Setälä kirjasi ylös Nyströmin puukirkkoluennolla: "Paljon muotokäsittelyä, joka on katoamaisillaan siksi, että emme intreseeraudu niistä". ${ }^{7}$

Nyström luokitteli Suomen puukirkot rakenteen perusteella syksyn 1914 luentosarjassaan. Hän jakoi ne kolmeen ryhmään: yksilaivaiset, joissa oli suora kuori (muiden muassa Saloinen, Tornio ja Hailuoto), yksilaivaiset, joissa oli kolmisivuinen kuori (Sottunga) ja ristikirkot. Jälkimmäiset hän jakoi sittemmin puukirkkotutkimuksissa toistuneihin tyyppeihin eli ulkoviisteisiin, 24-kulmaisiin ja kahtamoisiin. Kyseessä on ilmeisesti varhaisin Suomen puukirkkojen jaottelu rakenteen perusteella. Jotkut Suomen puukirkoista olivat samankaltaisia kuin Ruotsissa, ja Nyström vertasi niitä Suomen kirkkoihin. Ulkomaisista vaikutteista huolimatta koti- maan puukirkoissa näkyi hänen mukaansa kansallinen omaleimaisuus, ja siksi niillä oli erityinen, pysyvä arvo. ${ }^{77}$

Nyström kiinnitti puukirkot jo vuosikymmeniä esillä olleeseen ajatukseen siitä, kuinka kansalle ominainen henki, sen omintakeiset piirteet, ilmenivät kansan omissa rakennuksissa. Nyström luonnehti lämpimän tunteellisesti kotimaan puurakennuksia, joissa kiteytyivät entisaikojen elämä köyhissä olosuhteissa ja työ, jolle tuleva hyvinvointi perustui. Kansan omat puurakennukset olivat vaatimattomia, mutta kodikkaita. Hän luennoi arvostavasti aikaisempien vuosisatojen työmiesten taitavuudesta ja silloisen rakennusmateriaalin erinomaisuudesta. Kouluttamattomien kansanrakentajien ja toisaalta paikallisen materiaalin eli puun mestarillisen käytön kautta Nyström sitoi rakennukset käsityksiin suomalaisille ominaisesta ja vuosisatojen tai jopa vuosituhansien kuluessa jalostuneesta rakennusperinteestä.

Nyström kertoi löytäneensä Suomen puukirkoista "paljon omituisuuksia" ja "intressantteja asioita" niin muodoista kuin rakenteistakin. ${ }^{78}$ "Tällaisia muotoja en ole nähnyt muualla kuin Suomessa", Nyström luennoi opiskelijoilleen ja ylisti puukirkkojen 
puisia rakenteita paitsi materiaalille sopiviksi myös kauniiksi. Saloisten kirkossa myös kattorakenne oli erityinen. "Elegantti ja fixu konstruktio", Salme Setälä kirjoitti muistiinpanoihinsa. ${ }^{79}$ Rakenteiden ainutlaatuisuuden lisäksi Nyström korosti puukirkkojen esteettisiä arvoja. Saloisten kirkon ohella Seiskarin pieni kirkko oli Nyströmin mielestä erityisen kiinnostava: "Seiskari on kauneimpia, menkää sinne mittaamaan!" hän kehotti luennollaan. ${ }^{80}$ Maan kauneimpiin kuului hänen mielestään myös tuolloin jo purettu Kuolemajärven vanha ristikirkko erikoisine tapuleineen. ${ }^{81}$

Vanhat, yksinkertaiset, mutta tunnelmalliset kirkot tarjosivat Nyströmin mukaan paljon ajattelemisen aihetta uusien kirkkojen suunnittelijoille: ne olivat "tosia", niillä oli "karaktääri", ja ne olivat esimerkkejä siitä, kuinka rakennuksen henki oli tärkeämpi kuin ulkoinen koreus. ${ }^{82}$ Hän yritti välittää opiskelijoilleen ajatusta siitä, että kotimaan arkkitehtuuri oli aivan yhtä arvokasta kuin taiteen keskuksissa. Nyström liitti luennoissaan puukirkot arkkitehtuurikeskusteluissa jo pitkään toistettuihin ihanteisiin totuudenmukaisuudesta, rakennukselle ominaisen luonteen ilmaisusta ja liiallisen koristelun vahingolli- suudesta. Samalla hän painotti niiden kautta ajatuksiaan arkkitehtuurin ikuisena samana pysyvistä lainalaisuuksista ja siitä, että nykyisten arkkitehtien tuli ottaa oppia edeltäjiensä töistä ja edistää siten omalta osaltaan arkkitehtuurin kehittymistä. ${ }^{83}$

Kesämatkoillaan Nyström keräsi puukirkoista materiaalia tulevaa julkaisua varten. Vuonna 1915 senaatti myönsi hänelle 1200 markan apurahan kotimaan vanhojen rakennusten ja erityisesti puukirkkojen valokuvaamiseen ja mittaamiseen. Teknillinen korkeakoulu antoi puolestaan 2500 markkaa "Suomen vanhempia puukirkkoja" käsittelevän teoksen piirustuskuluihin ja kuvalaattojen valmistukseen. ${ }^{84}$ Nyström perusteli apuraha-anomustaan seuraavalla selostuksella kotimaan rakennusperinnön siihenastisesta tutkimuksesta:

En viktig grupp af våra äldre byggnader har under detta undersökningsarbete hitintills mycket för summats, nämligen träkyrkorna. De äldre ibland dem, som i många afseende äro de mest värdefulla, utgöra snart ett minne blott. I vår byggnadshistoria hafva de dock spelat en viktig rôl och de gömma en skatt af erfarenhet och sund, inhemsk byggnadstradition, som icke borde få gå helt förlorad för kommande släkten. ${ }^{85}$

[Tärkeä osa vanhemmasta rakennuskannastamme on tutkimustyön aikana aiemmin jätetty vaille huo- miota, nimittäin puukirkot. Vanhimmat niistä, jotka monessa mielessä ovat arvokkaimpia, ovat pian muisto vain. Rakennushistoriassamme niillä on kuitenkin ollut tärkeä rooli, ja niissä piilee kokemus ja terve kotimainen rakennustraditio, jota ei pitäisi hukata tulevilta sukupolvilta.]

Nyströmin mukaan puukirkot olivat terveen, kotimaisen puurakennusperinteen arvokkaita ilmentymiä. Niiden hirsirakenteissa tiivistyi kokemus siitä, millä tavoin puuta saattoi käyttää teknisesti parhaalla ja samalla esteettisesti korkealaatuisella tavalla. Tulevilla arkkitehtisukupolvilla oli paljon opittavaa näistä ikiaikaisen perinteen viimeisistä todistajista.

Kotimaan rakennusperinnön tutkiminen, dokumentointi, suojelu ja tiedon levittäminen niistä esitelmin ja julkaisuin tähtäsivät Nyströmin ajattelussa samaan päämäärään: uuden taiteen ja arkkitehtuurin kehittämiseen. Ainoastaan traditioon kiinnittymällä ja sitä jatkamalla uusi arkkitehtuuri voisi olla merkityksellistä, kehittyä kansainvälisesti korkeatasoiseksi ja ylittää aiemmat saavutukset. Tämän päämäärän saavuttamisen tärkein edellytys oli vanhojen rakennusmonumenttien säilyminen. ${ }^{86}$ Luennollaan Suomen puukirkoista Nyström siteerasi tanskalaisen Vilhelm Lorenzenin 
sanoja koskien kotimaansa rakennusperintöä:

Det vi ärft i byggnadsväg af våra fäder är som ett kapital, satt på ränta. Hur stor räntan är kan ej pedantiskt uppmätas, men hon finnes. Våra goda, gamla byggnader höra, menskligt och nationelt sett, till det mest värdefulla vi äga! ${ }^{87}$

[Isiltä perityt rakennuksemme ovat kuin pääoma, joka kasvaa korkoa. Koron suuruutta on mahdotonta tarkasti laskea, mutta se on olemassa. Vanhat hyvät rakennuksemme ovat, inhimillisesti ja kansallisesti katsottuna, arvokkainta omaisuuttamme!]

Nyströmin kirjoituksista selviää, että hän ajatteli jonkinlaista kansallista arkkitehtuuria tieksi pois "hermostuneesta rauhattomuudesta", liiallisesta individualismista ja uutuudentavoittelusta, joka hänen mukaansa 1900-luvun alussa vallitsi suomalaisten arkkitehtien keskuudessa. Kaikkein läheisimmiltä tuntuivat nimittäin ne rakennukset, joiden parissa inmiset olivat kasvaneet ja jotka vastasivat heidän kauneuden tarpeeseensa. Jokaisen kansan arkkitehtuurista löytyi arvokas perusta uudelle arkkitehtuurille. ${ }^{88}$ Kotimaista rakennusperintöä ei tullut kuitenkaan Nyströmin mukaan jäljitellä sellaisenaan, vaan tärkeintä oli ottaa sen "totuudellisuudesta" ja sopivuudesta opiksi. ${ }^{89}$

Nyström edisti kaikin tavoin kotimaan rakennusperinnön tutkimista. Elokuussa 1917 hän kirjoitti veljelleen Alexanderille: "Koen niin voimakkaasti tutkimusten ja oman maan muinaistaiteen keräämisen hyödyn, että haluan omistautua sille kokonaan."90 Hän oli varsin tietoinen siitä, että toisin kuin kirjoilla, arkistoihin kerätyllä materiaalilla ei ollut vaikutusta arkkitehteihin. ${ }^{91}$ Muut työt veivät kuitenkin paljon aikaa, ja hänen pitkään valmistelemansa julkaisusarja vanhasta suomalaisesta kirkkoarkkitehtuurista ei ehtinyt valmistua ennen hänen kuolemaansa 30.12.1917.

Nyströmin julkaisemattomat tutkimukset jatkoivat kuitenkin osittain elämäänsä hänen oppilaansa Carolus Lindbergin tutkimuksissa. Lindberg julkaisi yleisteoksensa Suomen kirkkoarkkitehtuurista vasta myöhemmin, mutta vain muutama vuosi Nyströmin kuoleman jälkeen, aivan 1920-luvun alkuvuosina, hän jakoi tietojaan Suomen puukirkoista Josef Strzygowskille. Lindberg esitteli Strzygowskille Teknillisen korkeakoulun mittauspiirustusmateriaalin ja vei tämän paikan päälle Keuruun ja Petäjäveden kirkkoihin. ${ }^{92}$ Lindbergin voi siten tulkita toimineen Nyströmin ideoiden välittäjänä.

\section{Lopuksi}

Tämän tutkimuksen valossa Gustaf Nyström oli Suomen puukirkkojen ja ylipäätään ra- kennustutkimuksen edelläkävijä, joka koulutti tulevat arkkitehdit kädestä pitäen mahdollisimman tarkkaan vanhojen rakennusten dokumentointiin. Kotimaan rakennusperinnön tutkiminen, mittaaminen, piirtäminen ja valokuvaaminen olivat osa laajempaa koulutushanketta, jonka yhtenä tärkeänä tavoitteena oli saada nuoret opiskelijat tarkastelemaan vanhoja rakennuksia ainutlaatuisina taideteoksina, joiden säilymisestä oli pidettävä huolta. Kaikkein tärkeimpänä tavoitteena oli kuitenkin uuden, kansallisesti omalaatuisen ja kansainvälisesti korkeatasoisen arkkitehtuurin kehittäminen. Vanhojen rakennusten dokumentointi ja suojelu eivät olleet Nyströmin ajattelussa antikvaarista, vaan ennen kaikkea uuden luomiseen tähdännyttä toimintaa; tulevaisuuden korkeatasoisen arkkitehtuurin mahdollistaminen oli rakennusperinnön tutkimisen ja säilyttämisen olennainen ydin.

Luennoissaan Nyström toisti jatkuvasti ajatusta, jonka mukaan edellisten sukupolvien työtä oli kunnioitettava ja jatkettava. Hän pyrki luomaan yhteenkuuluvuuden tunnetta nykyisten ja entisten arkkitehtien välille, mikä oli tärkeää paitsi ammatti-identiteetin, myös ammattitaidon kannalta. Hän yritti välittää 
opiskelijoilleen ajatusta, jonka mukaan edeltävien sukupolvien kokemusta ja tietotaitoa piti kunnioittaa ja jalostaa eteenpäin. Vanhoista kirkoista välittyivät kotimaisen rakennusperinteen parhaat puolet, mistä tulevien arkkitehtien oli mahdollista ammentaa ratkaisuja uusiin suunnittelutehtäviinsä. Nyströmin mukaan Suomen puukirkkorakentamisen perinteessä tekniikka ja estetiikka yhdistyivät esimerkillisellä tavalla toisiinsa. Luennoillaan hän toi esiin, kuinka entisaikojen suomalaiset rakentajat olivat käyttäneet niissä kekseliäitä ja taidokkaita, puumateriaalille ominaisia rakenteellisia ratkaisuja. Samalla he olivat onnistuneet luomaan niihin erityisen tunnelman, joka puhutteli vuosisadasta toiseen. Tämä oli tavoiteltavaa jokaisen arkkitehdin työssä aikakaudesta riippumatta.

Nyströmiä voidaan pitää paitsi kotimaan rakennusperinnön dokumentoinnin merkittävänä edistäjänä, myös pohjalaisen tukipilarirakenteen "löytäjänä", aivan kuten Lars Pettersson arveli. Hänen luentojensa ja esitelmiensä johdosta tukipilarikirkkojen erityisyys oli todennäköisesti jo 1900-luvun alkuvuosina ja viimeistään vuonna 1916 arkkitehtiopiskelijoiden ja muiden aiheesta kiinnostuneiden tiedossa. Nyströmin mukaan
Suomen puukirkot olivat Norjan sauvakirkkoihin verrattava, kansainvälisesti ainutlaatuinen aarre, jonka säilyminen oli kaikin keinoin varmistettava.

\section{Viitteet}

1 Artikkeli perustuu Jenny ja Antti Wihurin rahaston tukemaan tutkimushankkeeseen arkkitehti Gustaf Nyströmistä, jonka olen toteuttanut yhdessä Teppo Jokisen kanssa. Kiitän lämpimästi Teppo Jokista erinomaisesta yhteistyöstä. Lisäksi haluan kiittää erityisesti Leena Valkeapäätä ja Rainer Knapasta kommenteista ja avusta tätä artikkelia valmistellessani.

2 Käytän tästä vuonna 1930 palaneesta, PohjoisPohjanmaalla sijainneesta puukirkosta nimeä

Saloisten kirkko, vaikka sitä kutsutaan myös Salon kirkoksi.

3 Lars Pettersson, Templum Saloense: Pohjalaisen tukipilarikirkon arvoitus (Helsinki: Suomen

Muinaismuistoyhdistys, 1987), 23.

4 "Pettersson also discovered many new phenomena in the architecture of the wooden churches. One of the most interesting of these is the so-called Bothnian 'block-pillar' church". Henrik Lilius, "Lars Pettersson", Suomen Museo 1993: 6.

5 Renja Suominen-Kokkonen, "Studies of wooden churches in Finland: Josef Strzygowski and Lars Pettersson", Tahiti $4 / 2016$.

6 Anders Åman, "De nordiska träkyrkorna i ett internationellt perspektiv", teoksessa Kyrka af träd: Kyrkobyggande under 1600- och 1700-talen i Finland, Norge och Sverige. Red. Ingrid Sjöström (Stockholm: Riksantikvarieämbetet, 2000), 14; Janne Könönen, Unohduksista Unescoon: Petäjäveden vanhan kirkon vaiheet 1879-2014 (Petäjävesi: Petäjäveden vanhan kirkon säätiö, 2014).

7 Josef Strzygowski, "Finlands västkust i

träbyggnadskonsten", Hufvudstadsbladet 3.11.1923. Strzygowskin puukirkkotutkimuksista Suomessa Suominen-Kokkonen, "Studies of wooden churches": Katri Kähkönen, Josef Strzygowski ja Suomi:

Taidehistorian uusi rintama humanismia vastaan. Pro gradu -tutkielma, Historian laitos, Helsingin yliopisto, 2008.

8 Gustaf Nyströmistä restaurointiarkkitehtina Leena Valkeapää, Pitäjänkirkosta kansallismonumentiksi. Suomen keskiaikaisten kivikirkkojen restaurointi ja sen tausta vuosina 1870-1920 (Helsinki: Suomen Muinaismuistoyhdistys, 2000); Anna Ripatti, Jac. Ahrenberg ja historian perintö. Restaurointisuunnitelmat Viipurin ja Turun linnoihin 1800-Iuvun lopussa (Helsinki: Suomen Muinaismuistoyhdistys, 2011). 9 Vilhelm Helander, "Perinteen kantajat", teoksessa Hokos, Warma, Voloi...: taloja ja kyliä saaristosta,

Karjalasta ja Inkeristä, toimittanut Simo Freese (Helsinki: Pohjoinen, 1997).

10 Eliel Aspelin, Suomalaisen taiteen historia pääpiirteissään (Helsinki: Suomalaisen Kirjallisuuden Seura, 1891)

11 Gustaf Nyströmin kirjekonsepti Usko Nyströmille 25.12.1890. Nyström 2, Arkkitehtuurimuseo (MFA).

12 Gustaf Nyström, "Uppmätningar av äldre inhemska byggnadsverk utförda av studerande vid tekniska högskolan", Arkitekten 4/1917: 56; Polyteknillisen opiston vuosikertomus 1888-1889, 24; Polyteknillisen opiston opettajaneuvoston pöytäkirja 29.3.1889, Aalto-yliopiston arkisto (AA); KTT KD 18/143 1889 ja Senaatin talousosaston pöytäkirja 11.4.1889. Senaatin arkisto, Kansallisarkisto (KA).

13 Turun tuomiokirkon pitkäkestoisesta

restaurointihankkeesta Marja Terttu Knapas, Turun tuomiokirkon restaurointisuunnitelmat vuosilta 1896 ja 1901: Kansallisia ja kansainvälisiä tavoitteita rakennusmuistomerkkien hoidon alkutaipaleelta. Taidehistorian lisensiaatintutkimus, Helsingin yliopisto, 
1983

14 Kesällä 1890 Usko Nyström ja Henrik Reinhold Helin mittasivat ja piirsivät Hattulan ja Vanajan kirkot, Yrjö Sadenius ja Georg Hjalmar Åberg Pohjan kirkon. Jälkimmäinen oli Muinaismuistoyhdistyksen retkikunnan kohteena kesällä 1885, Hämeen kirkot kesällä 1887. Muinaismuistoyhdistyksen tutkimusmatkoista Leena Valkeapää, "Suomen muinaismuistoyhdistyksen taidehistorialliset tutkimusretket Suomessa 1871-1902", Tahiti 1/2018 ja hänen tuleva kirjansa, joka julkaistaan Suomen Muinaismuistoyhdistyksen Aikakauskirja -sarjassa. 15 Lähteiden perusteella vaikuttaa siltä, ettei Polyteknillisessä opistossa järjestetty yhteisiä mittauspiirustusmatkoja tammikuun 1892 ja kesän 1899 välisenä aikana. Todennäköisesti Nyström suositteli opiskelijoitaan Muinaismuistoyhdistyksen taidehistoriallisiin retkikuntiin, jotka koostuivat tuolloin lähes yksinomaan nuorista arkkitehdeistä ja arkkitehtiopiskelijoista. 16 Kauppa- ja teollisuustoimituskunnan akti SD HE 971/212 1915, Senaatin arkisto, KA; Nyström, "Uppmätningar av äldre inhemska byggnadsverk", 56; Salme Setälä, Polusteekin koulussa: Opiskelua kymmenluvulla (Helsinki: Otava, 1970), 124.

17 Kesällä 1909 Nyström järjesti Turun tuomiokirkon Kankaisten kappeliin valokuva- ja piirustusnäyttelyn Suomen vanhoista kirkoista. Näyttely kuului

Pohjoismaiden arkkitehtien tapaamisen ohjelmaan.

"Det skandinaviska arkitektbesöket", Åbo

Underrättelser 4.7.1909.

18 Teknillisen korkeakoulun opettajaneuvoston pöytäkirja 27.4.1911, AA. Avustus käytettiin pääasiassa vasta vuosina 1915-1916, jolloin Nyströmin apulaisena toimi arkkitehti Aarne Eklund. Nyström 44: 104, MFA. Kiitän Teppo Jokista tästä tiedosta.

19 Teknillisen korkeakoulun opettajaneuvoston pöytäkirja 12.12.1912, AA.

20 "Tekniska högskolans utställning", Teknikern 1913 323.

21 Teknillisen korkeakoulun vuosikertomus 1915-
1916, 34

22 "Gustaf Nyström 60 år" ja "Avritningar av äldre finska byggnader", Arkitekten 1916: 1-7.

23 Sveitsin kansanrakennusten tutkimisen ja Zürichin Polyteknillisen koulun opetustoiminnan yhteydestä 1800-luvun jälkipuolella, Knut Stegmann, "Analysing Historical Timber Structures. A Case Study on Ernst Gladback (1812-1896) and His Research on the 'Swiss Style'", teoksessa Nuts \& Bolts of Construction History. Culture, Technology and Society. Vol 1 ,

toimittaneet Robert Carvais, André Guillerme, Valérie Nègre \& Joël Sakarovitch (Paris: Picard, 2012), 3-10. 24 G. Nyström, Föreläsningar i arkitektur. Nyström 21, MFA.

25 Nyström viittasi toistuvasti Tanskan esimerkkiin: Träkyrkor i Finland. Nyström 26: 32 MFA; G. Nyström, "Vår egen byggnadskonst", Teknikern 1/1916: 14; Nyström, "Uppmätningar av äldre inhemska byggnadsverk", 56. Myös Muinaismuistoyhdistys piti tanskalaisten

dokumentointitapaa esimerkillisenä. Valkeapää,

"Suomen Muinaismuistoyhdistyksen taidehistorialliset tutkimusretket", 19.

26 Erik Hansen, "Indledning", teoksessa

Opmaalinger: Foreningen af 3. December 1892

(København: Kunstakademiets Forlag Arkitektskolen og Arkitektens Forlag, 1992), 11.

27 Svensk Arkitektur: Uppmätningar af äldre svenska byggnadsverk jämte fotografireproduktioner och beskrifvande text (Stockholm:

Arkitekturminnesföreningen, 1908), 1. Nyström viittasi tähän puukirkkoluennoillaan vuonna 1914. Träkyrkor i Finland, Nyström 26: 32, MFA.

28 Muinaistieteellisen toimikunnan pöytäkirja 17.6.1904, MV.

29 Kesällä 1903 Nyström matkusti usean opiskelijansa kanssa Pohjoismaiden arkkitehtien tapaamiseen Tanskaan. Kesäkuussa 1907 hän johdatti yhdessä Usko Nyströmin kanssa 19 arkkitehtiopiskelijaa Kööpenhaminaan ja Lyypekkiin. Samankaltainen matka toteutui myös keväällä
1912. Tiedot Polyteknillisen opiston ja Teknillisen korkeakoulun vuosikertomuksista.

30 Kauno S. Kallio, "Toiselta pohjoismaiselta arkkitehtiretkeltä Tanskassa", Rakentaja 5/1903: 36. Artikkeli jatkui lehden seuraavassa numerossa Arkkitehdit tutustuivat tuolloin myös Tanskan keskiaikaisiin linnoihin ja kirkkoihin, muun muassa Ringstedin Pyhän Bendtin kirkkoon sen restaurointiarkkitehdin Herman Storckin johdolla. Kiitän Teppo Jokista näistä tiedoista.

31 "Herr Professorns råd att lägga oss till med Tegningar af ældre nordisk Arkitektur skall jag gerna följa, så mycket hellre som jag länge önskat att vi ägde något åt det hållet. - Vi och våra fäder här i Finland hafva allt för länga varit oförklarligt blinda för hvad som ligger oss närmast och som varit värdt att taga vara på här hemma i norden. Kanske är det den ständiga frosten, och hungersnöden här i landet som gjort att Italien alltid glimrat så härlig för vår fantasi, att vi aldrig haft ro att stanna i Danmark eller Sverige, då vi varit nog lyckliga att slippa ut! Besöket i Danmark för två år sedan har äfven i detta afseende gifvit oss mycket att tänka på." G. Nyström Hans J. Holmille 25.3.1905. Nyström 8: 112-115, MFA.

32 G. Nyström Georg Bestlelle Kööpenhaminaan 26.5.1914. Nyström 10: 60, MFA; Nyströmin oppilas Carolus Lindberg käytti samaa Nyropin mottoa väitöskirjassaan. Carolus Lindberg, Om teglets användning i finska medeltida gråstenskyrkor (Helsingfors: H. Schildt, 1919), 5.

33 Teknillisen korkeakoulun vuosikertomus 19141915, 46.

34 Nyströmin korjausehdotukset Lindbergin väitöskirjan käsikirjoitukseen, Arkkitehtuurin laitos, Aalto-yliopisto.

35 Viittauksia Suomen Muinaismuisto-Yhtiön tarkoituksesta ja vaikutusalasta. (Helsinki, 1871), 22. Seuraavassa, vuoden 1892 painoksessa puukirkkoja koskeva osuus pysyi samana, mutta epäselvää kieltä oli korjattu. Kiitän Leena Valkeapäätä tätä lähdettä ja Muinaismuistoyhdistyksen taidehistoriallisia

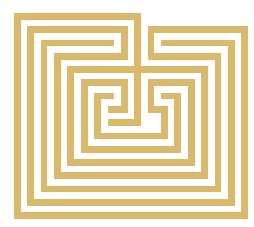


retkikuntia koskevista tiedoista.

36 Aspelin, Suomalaisen taiteen historia, 29.

37 Valkeapää, "Suomen muinaismuistoyhdistyksen

taidehistorialliset tutkimusretket", 13.

38 Ritva Wäre, Rakennettu suomalaisuus:

Nationalismi viime vuosisadan vaihteen

arkkitehtuurissa ja sitä koskevissa kirjoituksissa

(Helsinki: Suomen Muinaismuistoyhdistys, 1991);

Helena Lonkila, Syvällä Sydänmaassa: Yrjö

Blomstedtin ja Victor Sucksdorffin Kainuu (Jyväskylä:

Jyväskylän yliopisto 2016).

39 Emil Nervander, "Kesämatkoja Suomessa. Pohjois

Pohjanmaalla." Päivälehti 22.7.1896.

40 "Det låg en liten honnör för dess okände målare

i det skämtnamn, man på utställningen hörde

besökare gifva den lilla, landtliga, murknande kyrkan:

'Finlands San Marco."' Emil Nervander, "Finska

Fornminnesföreningens utställning i Helsingfors den

28-31 Mars 1897", Finskt Museum 7-10/1897: 77;

Pettersson Templum Saloense, 51.

41 Nyström erosi Muinaistieteellisestä toimikunnasta vuonna 1908.

42 Emil Nervanderista Muinaistieteellisen toimikunnan lausunnonantajana Leena Valkeapää, Vapaa kuin

lintu: Emil Nervanderin elämä (Helsinki: Taidehistorian Seura, 2015), 101, 104-111.

43 G. Nyströmin päiväämätön käsikirjoitus [1906],

Arkkitehtuurin laitos, Aalto-yliopisto.

44 Henkilötiedot teoksessa Nimikirja Suomen

Polyteknillisen Opiston opettajista ja oppilaista

1898-1908, toimittanut Sulo Heiniö (Hämeenlinna:

Arvi A. Karisto, 1918), 218, 220, 242-243.

45 Paatola työskenteli Nyströmin toimistossa vuonna 1904, Uotila vuonna 1905. Teppo Jokisen keräämät

tiedot koskien Nyströmin toimistossa työskennelleitä oppipoikia.

46 "En intressant konsthistoris (sic) utställning",

Hufvudstadsbladet 8.12.1905.

47 "Liksom i allmänhet våra landskyrkor från 1600-

och 1700-talen äro de nordösterbottniska från

samma tid mycket oansenliga och af en ytterst torftig arkitektur såväl ut- som invändigt.” J. J. Tikkanen, "Finska fornminnesföreningens utställning", Finsk Tidskrift 4/1897: 300. Kiitän Leena Valkeapäätä tämän lähteen tiedoista.

48 Lähteessä "originell, rik och pittoresk". J. J.

Tikkanen, "Finska fornminnesföreningens utställning", 300.

49 Muinaistieteellisen toimikunnan pöytäkirja 27.2.1897, MV; Riitta Nikula, "Armas Lindgren och den historiska arkitekturen", Taidehistoriallisia tutkimuksia 9 (Helsinki: Taidehistorian seura, 1986), 146-147.

50 G. Nyströmin kirje J. R. Aspelinille 20.3.1897.

Topografinen arkisto: Kärkölä, MV. Ote Nyströmin kirjeestä julkaistu Nikula, "Armas Lindgren och den historiska arkitekturen", 146-147.

$51 \mathrm{H}$ [aniel].Ö[string]., "Muistomerkeistä Raahessa ja Salon pitäjäässä", Oulun Lehti 24.5.1884.

52 Peregrinus [Eliel Aspelin], "Anteckningar under en resa II. Salo kyrka", Wasabladet 2.8.1884; Pettersson,

Templum Saloense, 45.

53 Raahen ja Salon kirkkoherranviraston kirje

"Suomen Arkeoloogiselle komissioonille" 18.5.1896.

Topografinen arkisto: Saloinen, MV

54 Muinaistieteellisen toimikunnan pöytäkirja

28.5.1896, MV; Valkeapää, "Suomen

muinaismuistoyhdistyksen taidehistorialliset

tutkimusretket", 14.

55 Kopio valtionarkeologin kirjeestä Raahen ja Saloisten kirkkoherranvirastolle 1.11.1897. Topografinen arkisto: Saloinen, MV.

56 Raahen ja Saloisten kirkkoherranviraston kirje valtionarkeologille 3.11.1897. Topografinen arkisto: Saloinen, MV.

57 G. Nyströmin kirje Agi Lindegrenille 17.12.1900. Nyström 6: 162, MFA.

58 Muinaistieteellisen toimikunnan pöytäkirja

31.3.1898, MV; Kopio MV:n kirjeestä Keisarille

31.3.1898 ja Muinaistieteellisen toimikunnan lausunto

12.9.1901. Topografinen arkisto: Saloinen, MV.

59 G. Nyströmin kirje W. A. Tötterströmille
12.5.1898. Topografinen arkisto: Saloinen, MV; Muinaistieteellisen toimikunnan pöytäkirja 26.5.1898,

MV; Pettersson Templum Saloense, 52

60 Emil Nervanderin kirje valtionarkeologille

26.1.1899. Topografinen arkisto: Saloinen, MV

61 Muinaistieteellisen toimikunnan pöytäkirja

8.2.1899, MV.

62 Muinaistieteellisen toimikunnan pöytäkirja

30.6.1899, MV.

63 Muinaistieteellisen toimikunnan pöytäkirja

30.6.1899; Muinaistieteellisen toimikunnan lausunto

14.2.1901. Topografinen arkisto: Saloinen, MV.

64 Lars Pettersson, Suomalainen puukirkko, 6-7.

65 Armas Lindgren visioi Saloisten vanhan kirkon

siirtämistä pääkaupungin ulkoilmamuseoon. Nikula,

"Armas Lindgren och den historiska arkitekturen",

149.

66 G. Nyströmin kirje V. Sucksdorffille 13.11.1900.

Nyström 06: 148, MFA; Victor Sucksdorffin lausunto

14.1.1899 \& kirje G. Nyströmille 16.11.1900.

Topografinen arkisto: Saloinen, MV.

67 Muinaistieteellisen toimikunnan pöytäkirja

12.12.1900; Muinaistieteellisen toimikunnan lausunto

14.2.1901. Topografinen arkisto: Saloinen, MV.

68 Gustaf Nyström, "Salo Kyrka", Tekniska

Föreningens i Finland Förhandlingar 2/1902: 47-49.

69 Träkyrkor i Finland, CXIX. Nyström 26, MFA.

70 G. Nyströmin kirje H. B. Storckille 19.12.1903. Det

Kongelige Bibliotek, Kööpenhamina. Collection: NKS 2713, $2^{\circ} \mathrm{I}, 2$.

71 Piirustukset ja diat mainitsee Hufvudstadsbladet 16.3.1916.

72 G. Nyströmin kirje Alexander Nyströmille 14.3.1916. Nyström 10 (irrallinen kirjekopio), MFA.

73 Träkyrkor i Finland. Nyström 26, MFA.

74 Hufvudstadsbladet 29.12. ja 30.12.1914.

75 Träkyrkor i Finland. Nyström 26, MFA; Salme

Setälän muistiinpanot G. Nyströmin kurssilta Suomen

puukirkot 1914. Setälä 7 MFA.

76 Salme Setälän muistiinpanot G. Nyströmin

kurssilta Suomen puukirkot 24.11.1914. Setälä 7,

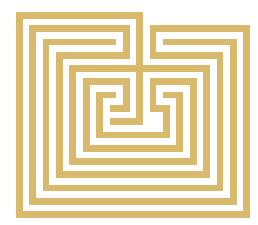


MFA.

77 Träkyrkor i Finland. Nyström 26 MFA; Salme Setälän muistiinpanot G. Nyströmin kurssilta Suomen puukirkot 1914. Setälä 7, MFA

78 Träkyrkor i Finland. Nyström 26 MFA; Salme

Setälän muistiinpanot G. Nyströmin kurssilta Suomen puukirkot 16.11.1914. Setälä 7, MFA.

79 Träkyrkor i Finland. Nyström 26 MFA; Salme

Setälän muistiinpanot G. Nyströmin kurssilta Suomen

puukirkot 16.11.1914. Setälä 7, MFA

80 Salme Setälän muistiinpanot G. Nyströmin

kurssilta Suomen puukirkot 16.11.1914. Setälä 7 ,

MFA.

81 Salme Setälän muistiinpanot G. Nyströmin

kurssilta Suomen puukirkot 24.11.1914. Setälä 7,

MFA.

82 Träkyrkor i Finland. Nyström 26, MFA.

83 Nyströmin arkkitehtuurikäsityksistä Ville

Lukkarinen, Classicism and History. Anachronistic

Architectural Thinking in Finland at the Turn of

the Century. Jac. Ahrenberg and Gustaf Nyström

(Helsinki: Suomen Muinaismuistoyhdistys, 1989).

84 SD HE 971/212 1915, KA; Nyströmin anomus

Suomen Keisarillisen Senaatin Kauppa- ja

teollisuustoimituskunnalle 7.6.1915. Nyström 17:

298-300; Nyström 48/Matkarahat, MFA; Teknillisen

korkeakoulun opettajaneuvoston pöytäkirja 28.5.1915,

AA; Teknillisen korkeakoulun vuosikertomus 1914

1915, 36; Finlands Allmänna Tidning 20.08.1915.

85 G. Nyström Senaatin Kauppa- ja

teollisuustoimituskunnalle. SD HE 971/212 1915, KA

86 Tätä ajatusta Nyström yritti tähdentää muun

muassa kirjeessään Tötterströmille 12.5.1898.

Topografinen arkisto: Saloinen, MV.

87 Träkyrkor i Finland. Nyström 26: 36, MFA.

88 G. Nyström 19.6.1914. Nyström 21, MFA.

89 Nyström, "Vår egen byggnadskonst", 14.

90 "Nyttan af undersökningarna och samlandet af det

egna landets fornkonst känner jag så djupt att j[ag] vill

gifva mig helt åt det arbetet." G. Nyström, "Alexander,

12.8.1917. Skrifvit då ja var sjuk. Icke afsändt",
Nyström 10: 145-148, MFA.

91 G. Nyström Svenska Litteratursällskapet

Finlandille 18.10.1914. Nyström 17: 204-206, MFA.

92 Josef Strzygowski, "De gamla träkyrkorna i Keuru

och Petäjävesi", Hufvudstadsbladet 14.10.1923;

Suominen-Kokkonen, "Studies of wooden churches".
FT, taidehistorioitsija Anna Ripatti toimii

Maija Lehtonen yliopistotutkijana Helsin-

gin yliopistossa. Hän on tutkinut 1800-lu-

vun arkkitehtuuria, restauroinnin historiaa

ja taidehistorian tutkimushistoriaa.

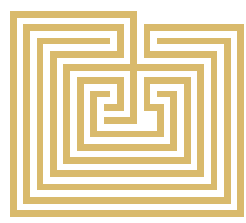

